\title{
Uma Trilogia do Poder \\ Crónica de D. Afonso V, Painéis de São Vicente de Fora e Tapeçarias de Pastrana
}

\author{
Carlota Bellino Vieira de Castro \\ carlotalemur@gmail.com
}

\section{Resumo}

Partindo do pressuposto de que as imagens, enquanto fruto de um tempo, carregam em si vestígios de uma realidade histórica, o presente artigo, que se centra no ano de 1471 prende-se com as representações do poder presentes nas Tapeçarias de Pastrana e nos Painéis de São Vicente. Assim, ao procurar entender o verdadeiro significado da imagem a associada a Afonso V, será aplicado o método de investigação iconográfica desenvolvido por Erwin Panofsky. O texto da Crónica de D. Afonso V, embora o único elemento desta trilogia do poder que não foi encomendado pelo próprio monarca, é também indispensável ao entendimento da figura que a dinastia de Avis pretendia construir, sendo certo que os soberanos não quiseram apenas imortalizar uma visão de si mesmos, mas também da sua geração e do seu reino enquanto um todo.

Palavras-chave: Afonso V; Crónica de D. Afonso V; Painéis de São Vicente de Fora, Tapeçarias de Pastrana.

\begin{abstract}
Based on the assumption that the images, as a result of time, carry traces of a historical reality, the present article, which focuses on the year 1471, deals with the representations of power present in Tapeçarias de Pastrana and Painéis de São Vicente. Thus, when trying to understand the true meaning of the image associated with Afonso V, the method of iconographic investigation developed by Erwin Panofsky will be applied. The text of the Crónica de D. Afonso V, although the only element of this trilogy of power that was not commissioned by the monarch himself, is also indispensable for the understanding of the figure that the Avis dynasty intended to build, being certain that the sovereigns did not just want to immortalize a vision of themselves, but also of their generation and their kingdom as a whole.
\end{abstract}

Keywords: Afonso V; Crónica de D. Afonso V; Painéis de São Vicente de Fora, Tapeçarias de Pastrana. 


\section{Introdução}

Sabe-se que $O$ Africano cultivava a sua imagem, sobretudo depois dos anos dourados de Alcácer Ceguer, Arzila e Tânger. Sabe-se, de igual modo, que, a partir do Quattrocento, o mecenato aumentou exponencialmente devido a uma maior quantidade de dinheiro em circulação. Com o aumento do mecenato, cresceu a encomenda, uma vez que os grandes senhores dos séculos XV e posteriores consideravam que a arte tinha um papel fundamental na construção de uma imagem política, social e económica. Vivia-se, portanto, uma realidade cultural circular: os comitentes necessitavam dos artistas para construírem a sua imagem, e os artistas necessitavam dos comitentes, não só para poderem continuar a produzir, mas também para ascenderem socialmente. Mais do que o reconhecimento da nobreza da sua arte, foi a necessidade dos artistas - sustentada pelas cortes que procuravam a originalidade e a novidade - que conduziu ao dinamismo destas cronologias.

D. Afonso V, impregnado de um sentido de missão e de cruzada, no seu entender justo, bélico e cristão, procurou legar à história uma imagem hagiográfica e glorificada, por si edificada. Foi esta vontade que o levou a ordenar e a idealizar, a par das duas séries de Pastrana, o políptico de veneração a São Vicente, em clara complementaridade simbólica e ideológica ${ }^{1}$.

Esta vontade do monarca de atingir da imortalidade fora já demonstrada na exposição $A$ Invenção da Glória, apresentada no Museu Nacional de Arte Antiga de 12 de junho a 12 de setembro de 2010. Segundo António Filipe Pimental, diretor do mesmo museu ao tempo da sobredita exposição,

em todos [os panos encomendados por D. Afonso V], com efeito, se expressa o mesmo anseio de criar uma imagem para a História: de inventar um registo de glória, ao Reiguerreiro, que nelas faz prova [...] de uma aguda e moderna ciência da importância operativa dos meios cénicos e visuais, denunciadora de uma formação intelectual já impregnada de heroísmo ${ }^{2}$.

A ânsia de ver a sua glória reconhecida era tanta para os homens do século XV e seguintes, que muitos procuravam realizar pomposos eventos que refletissem o seu poder. "Las fiestas realizadas con motivo de las coronaciones, por ejemplo, eran un recurso necesario para sublimar las ideas de prestigio y poder político a través de una ostentación pública y fastuosa del mismo"3. D. Afonso V, enquanto monarca imbuído do espírito humanista caraterístico do seu tempo, configurou-se como antecessor do programa altamente simbólico iniciado por D.

\footnotetext{
${ }^{1}$ HENRIQUES, Ana de Castro (coord.) - A Invenção da Glória: D. Afonso V e as Tapeçarias de Pastrana. Lisboa: Museu Nacional de Arte Antiga, 28 de maio de 2010. p. 12.

2 PIMENTEL, António Filipe - D. Afonso V e a Invenção da Glória. As Tapeçarias de Pastrana no Museu Nacional de Arte Antiga. In HENRIQUES, Ana de Castro (coord.) - A Invenção da Glória: D. Afonso V e as Tapeçarias de Pastrana. Lisboa: Museu Nacional de Arte Antiga, 28 de maio de 2010. pp. 10-11.

${ }^{3}$ ALCAIDE, Victor Nieto; CREMADES, Fernando Checa - El Renacimiento: Formación y crisis del modelo clásico. $3^{\mathrm{a}}$ edição. Madrid: Ediciones Istmo, 1985. p. 109.
} 
Manuel I, tanto na Sala dos Brasões do Palácio de Sintra, como na embaixada que O Venturoso enviou à cúria romana ${ }^{4}$.

Tomando-se o ano de 1471, ano em que "[...] ennovou e acrescentou ElRey o titulo que tinha, e se intitulou nova e prymeiramente per esta maneira Dom Afonso per graça de Deos Rey de Portugal e dos Algarves, daa quem e daalém mar em Africa [...]"5 como cronologia fulcral, a minha leitura do texto de Rui de Pina centrou-se nos capítulos $162^{\circ}$ a $167^{\circ}$. Estou, todavia, ciente de que os textos da cronística assumiam, acima de tudo, uma função pedagógica de educação dos jovens príncipes, pelo que devem ser interpretados e questionados, no sentido de permitirem avançar um pouco mais no conhecimento, ainda que, numa investigação em história, a verdade seja um horizonte inalcançável.

\section{Algumas Considerações Sobre o Reinado de D. Afonso V*}

El-rei D. Duarte faleceu em Tomar, na quinta-feira dia 9 de setembro de 1437, dia em que, segundo a cronística, “[...] per espaço de duas oras o Sol em grande cantydade foy cris [...]"6 , fenómeno que já havia ocorrido aquando das mortes de D. João I e de D. Filipa de Lencastre. Não é possível saber se, de facto, o sol se terá eclipsado à data da morte de O Eloquente, porém, independentemente de tal acontecimento, a intenção de Rui de Pina ao mencioná-lo é clara: enaltecer a figura do monarca falecido, mostrando que até o próprio sol fez o seu luto.

Com efeito, após a morte do soberano, muito se discutiu acerca da regência do reino. $\mathrm{O}$ testamento do monarca falecido apontava para que o governo do reino ficasse entregue a D. Leonor até à maioridade do príncipe Afonso, que chegou a ser alevantado a 10 de setembro do sobredito ano. No entanto, o Infante D. Pedro, não obstante ter jurado lealdade ao seu sobrinho “[...] como por mostrar a muytos de danadas maginaçooens, e aa Raynha Dona Lyanor pryncipalmente, que aquella fora sempre, e era sua leal e verdadeira tençaõ d'obedecer e nam a outra falsa de querer per força reinar [...]"', acabou por pressionar militar e politicamente a rainha até conseguir assumir a regência.

Para conseguir tomar o poder, o Duque de Coimbra rodeou-se de inúmeros juristas que, ancorando-se no direito imperial romano, negavam a capacidade das mulheres para governar. D. Leonor muniu-se das mesmas armas, mas os seus apoiantes baseavam-se no princípio da

\footnotetext{
${ }^{4}$ PIMENTEL, António Filipe - op. cit.

${ }^{5}$ PINA, Rui de - Chronica do Senhor Rey D. Affonso V. In. PINA, Rui de - Crónicas. Introd. de Manuel Lopes de Almeida; rev. de Manuel Lopes de Almeida. Porto: Lello \& Irmão, 1977. p. 825.

* Nesta secção encontram-se narrados apenas os acontecimentos relevantes para a tese que se pretende defender, a da tentativa de construção de uma imagem por parte do monarca. Neste sentido, este capítulo não tem qualquer pretensão de apresentar uma biografia mais ou menos completa de D. Afonso V.

${ }^{6}$ PINA, Rui de - Chronica do Senhor Rey D. Affonso V... p. 587.

${ }^{7}$ Idem, pp. 589-590.
} 
legalidade, fundado na vontade expressa no testamento de D. Duarte ${ }^{8}$. Se é verdade que o facto de a rainha ser estrangeira contribuiu para o seu descrédito, também o é que o preconceito acerca da menoridade intelectual das mulheres no medievo limitava o seu espaço de ação em todos os campos da sociedade. Segundo R. Howard Bloch,

[...] o tópico da misoginia, como a clava ou o cinto de castidade, compartilha um horror vestigial praticamente sinônimo da Idade Média, e porque uma das suposições que governam nossa percepção do cristianismo primitivo e do período medieval é a presença virulenta do antifeminismo9.

O mesmo autor cita Jean de Meun, um dos mais importantes poetas franceses do medievo, que, em Roman de la Rose, explicita algumas das caraterísticas psicológicas que a sociedade do seu tempo considerava como inerentes ao sexo feminino, e que impediam qualquer ambição de libertação das amarras domésticas:

Qu'il i a vie trop grevaine,

Pleine de travail et de paine

Et de contenz et de riotes,

Par les orguez des fames sotes,

Et de dangiers et de reproches

Qu'el fonte $t$ dient par leur boches,

Et de requestes et de plaintes

Qu'el treuvent par achesons maintes.

Si ra grant paine en eus garder

Por leur fous volairs retarder ${ }^{10}$.

Os argumentos de D. Pedro foram imbatíveis, pelo que D. Leonor se viu na posição de firmar a seguinte concordata: "Que com a Rainha ficasse o cargo da cryaçam de seus Fylhos; e com a governança e ministrança de toda a fazenda; e ao Yfante ficasse ho Regymento da Justyça, e o Tytulo de Defensor dos Reynos por ElRey" "11. Apesar da assinatura deste acordo, o futuro Africano acabou por perder a mãe muito cedo, tendo sido entregue aos cuidados do seu tio D. Pedro, que posteriormente derrotou na batalha de Alfarrobeira. Foi este trágico desfecho que levou a que Manuel Ramos escrevesse: “[...] [D. Pedro] com a vitória também assinou a sua sentença de morte que lhe estava reservada para o dia em que abandonasse a regência"12.

\footnotetext{
${ }^{8}$ RAMOS, Manuel Francisco - “«Mulier ne debuerit habere regnum»: a regência na menoridade de D. Afonso V vista pelos juristas”. Medievalista. [Em Linha]. Lisboa: IEM-FCSH. N. ${ }^{\circ} 23$ (2018)

${ }^{9}$ BLOCH, R. Howard - Misoginia Medieval e a Invenção do Amor Romântico Ocidental. Trad. de Cláudia Moraes. Rio de Janeiro: Editora 34. Distribuição pela Editora Nova Fronteira S.A., 1995. pp. 14-15.

${ }^{10}$ MEUN, Jean de - Roman de la Rose. Cit. por BLOCH, R. Howard - op. cit., p. 23.

${ }^{11}$ PINA, Rui de - Chronica do Senhor Rey D. Affonso V... p. 599.

${ }^{12}$ RAMOS, Manuel Francisco - op. cit., p. 9.
} 
D. Afonso V continua a ser considerado por alguns autores como um rei-cavaleiro, que tinha como objetivo único conseguir vitórias militares, podendo ignorar o bem-estar do seu povo - a título exemplificativo, refiro que levou o príncipe D. João consigo para o campo de batalha, correndo o risco de deixar o reino numa situação de interregno. Saúl António Gomes advoga que a forte influência materna na sua educação enquanto jovem ter-lhe-á incutido uma noção muito clara de identidade ${ }^{13}$, o que terá moldado a sua personalidade. Atrevo-me a colocar algumas questões a esta tese. Embora esteja ciente de que os primeiros anos de vida são os mais importantes no desenvolvimento do temperamento, e de que se Gomes avança com esta asserção alguma razão terá, face à morte precoce de $\mathrm{D}$. Leonor não me parece possível fazer uma afirmação tão categórica como a anteriormente enunciada.

Por uma razão ou por outra, D. Afonso V mostrou grande preocupação com a conquista de territórios em África, visando dar continuidade às políticas portugueses de controlo do Magrebe, facto que lhe valeu o cognome "O Africano". A sua ambição expansionista mostrouse clara desde os primórdios do seu reinado: depois da perda de Constantinopla, o soberano colocou-se disponível para fazer a cruzada junto do Papa Calisto III, em 1456, enviando uma armada portuguesa de pequenas dimensões para o Oriente ${ }^{14}$.

Corria o ano de 1471 quando uma esquadra formada por 477 embarcações de diversos tamanhos e cerca de 30000 homens desembarcou na cidade de Arzila ${ }^{15}$, que, juntamente com Tânger e Alcácer Ceguer, surgia como praça fundamental para garantir a segurança do reino de Portugal no contexto do eixo estratégico Atlântico-Mediterrânico ${ }^{16}$, uma vez que coroavam a península tingitana.

No prymeiro bote saíram logo com ElRey [D. Afonso V] muyta gente, toda bem armada [...]. E no dia em que ElRey sahio, logo pôs cerco aa Villa em torno de mar, cerrando e defensando seu arrayal com alta cava [...]. E começaram apressadamente de fazer seus tiros, e assy os espingardeiros e beesteiros não cessavam de combater $[\ldots]^{17}$.

Arzila foi tomada a 24 de agosto, tendo a empresa sido comandada por D. Afonso V com o apoio do príncipe herdeiro D. João, que, de resto, foi armado cavaleiro na mesquita da cidade.

A entrada na fortaleza da praça continua a ser alvo de reflexão, já que os muçulmanos tentaram negociar com o soberano uma rendição, quando o “[...] Alcayde da dita Vylla [Arzila]

\footnotetext{
${ }^{13}$ GOMES, Saúl António - D. Afonso V: o africano. Lisboa: Círculo de Leitores, 2006. 366 p. (Coleção Reis de Portugal, 2. ${ }^{a}$ dinastia, vol. 12).

${ }^{14}$ ARAÚJO, Inês Filipa Meira - As Tapeçarias de Pastrana: Uma Iconografia de Guerra. Lisboa: Faculdade de Letras da Universidade de Lisboa, 2012. Tese de mestrado.

${ }^{15}$ Cidade do noroeste de Marrocos, que faz parte da atual da região de Tânger-Tetuão. Situa-se a cerca de 40 quilómetros a sul por estrada de Tânger, numa planície junto à costa atlântica.

${ }^{16}$ Idem, p. 25.

${ }^{17}$ PINA, Rui de - Chronica do Senhor Rey D. Affonso V... pp. 820-821.
} 
lhe querya [a El-Rei] hir falar sobre concerto, que era tal que o devia aceitar"18, pedido a que o monarca acedeu. Contudo, o ataque precipitou-se sem ter sido dada ordem de início.

Embora Rui de Pina escreva que era intenção do monarca fazer cumprir o acordo com o alcaide de Arzila, atrevo-me a questionar se tal terá, de facto, ocorrido. Gomes alega que a grande motivação para a mudança de posição de O Africano terá sido o assassinato de D. Álvaro de Castro, Conde de Monsanto, mas não ignora que D. Afonso V terá desconfiado desde logo da proposta sarracena ${ }^{19}$. Quiçá o monarca sempre tivesse pretendido invadir a cidade, e o seu cronista apenas mascare tal vontade para deixar do seu soberano a imagem de um homem justo. Com efeito, rigorosamente o mesmo acontece na Crónica do Senhor Rey D. Duarte, na qual Rui de Pina relata que as cartas enviadas pelo Infante Santo a seu irmão "[...] moviam os olhos d'ElRey pera muytas lagrimas, e punham seu coraçom em muyta tristeza [...]"20, e onde eu ouso questionar até que ponto é que tal será verdade, uma vez que foi por decisão, entre outros, da própria Ínclita Geração que D. Fernando foi votado ao martírio.

Conquanto o objetivo principal da empresa marroquina tenha sempre sido Tânger, a verdade é que a tomada de Arzila se revelou muito proveitosa, ideia patente na inscrição da tapeçaria $O$ assalto a Arzila: das riquezas, a presa obtida foi maior do que era de esperar em vista o tamanho da cidade ${ }^{21}$. De resto, "[...] a mortyndade e estrago de Arzilla [...]"22 serviram de alarme para a investida portuguesa em Tânger, que apenas se consumou quando a cidade se encontrava "[...] vazia de suas pessoas e fazendas e chea de muyto fogo [...]"23. Gomes afirma que a versão dos acontecimentos narrada por Rui de Pina parece contradizer a de Jean de Wavrin, citando a transcrição de Jacques Paviot:

[quando o exército português entrou] toutte la ville estoit saine et entiere, sans y avoir esté en nulle part boutté le feu. Et trouverent les maisons bien estoffes de litz, de mesnage, de bléz, d'orge et poisson et tous aultres vivres, excepté char et vin, en sy grand habondance qu'ilz en ont assez pour iij [3] ou quatre ans. Et trouverent aussy bombardes, canons, poldres et toutte aultre artillerye en grant souffisance, car, adce que l'en dit, toutte la plus part et la meilleure artillerye y estoit ${ }^{24}$.

\footnotetext{
${ }^{18}$ Idem, p. 821.

${ }^{19}$ GOMES, Saúl António - op. cit., p. 194.

${ }^{20}$ PINA, Rui de - Chronica do Senhor Rey D. Duarte. In PINA, Rui de - Crónicas. Introd. de Manuel Lopes de Almeida; rev. de Manuel Lopes de Almeida. Porto: Lello \& Irmão, 1977. p. 821.

${ }^{21}$ ARAÚJO, Inês Filipa Meira - op. cit.

${ }^{22}$ PINA, Rui de - Chronica do Senhor Rey D. Affonso V... p. 824

${ }^{23}$ Idem, p. 570.

${ }^{24}$ Cit. por PAVIOT, Jacques - Portugal et Bourgogne au XV siècle (1384-1482). Récueil de documents extraits des archives bourguignonnes. Paris/Lisboa: Centre Culturel Calouste Gulbenkian - Commission Nationale pour les Commémorations des Découvertes Portugaises, 1995.
} 
Dez anos após a tomada de Arzila, ao vigésimo oitavo dia do mês de agosto, O Africano faleceu, possivelmente vítima dos diversos surtos de peste que assolaram o reino ao seu tempo ${ }^{25}$. A descrição redigida por Rui de Pina dos últimos momentos do monarca é breve e menos expressiva:

ElRey tendo feito seu testamento, e recebendo todollos sacramentos ally acabou, como bom e Catolico Cristam, dando sua alma a Deos [...] E na propria casa em que nasceo, ali morreo e acabou. Foy seu corpo logo metido em hum ataude, e posto sobre huma azemalla que com Cruzes, tochas, e Clerigos foy pollo Conde de Monsanto, que hy era, e per outros Fydalgos levado ao Moesteiro da Batallha, e enterrado na casa do Cabido, onde jaz atée aver sua sollene merecida sepultura ${ }^{26}$.

Gomes ressalva a necessidade de se comparar o relato de Pina, que opta por um silêncio que parece de ouro face às palavras que nos causam alguma desconfiança ${ }^{27}$, com o de Garcia de Resende, mais arrojado. Este cronista menciona a suspeição latente de envenenamento, sendo o príncipe D. João acusado por alguns membros da corte - e não pelo cronista - de estar envolvido em tal conspiração. Alude, no entanto, à satisfação sentida pelo soberano ao ver aproximar-se do seu leito o seu filho, tendo sido ele, motivado pela vontade de salvar a alma paterna, a conduzir os últimos momentos da vida do progenitor ${ }^{28}$. Se Rui de Pina escreve que terá sido o Conde de Monsanto o responsável pelo transporte do cadáver real, Garcia de Resende aponta para a intervenção do futuro O Príncipe Perfeito ${ }^{29}$. Face a esta contradição, parece-me importante ressalvar, mais uma vez, a agenda dos textos da cronística, podendo Garcia de Resende exaltar D. João não porque ele tenha, de facto, tido um papel relevante nesta circunstância, mas sim devido ao facto de ele ser o futuro monarca, sendo necessário solidificar a sua imagem enquanto modelo de virtude.

\section{Uma Trilogia do Poder}

A nível da exposição iconográfica, D. Afonso V foi sempre representado em concordância com a imagem presente nas tábuas da Genealogia do Infante D. Fernando: “[...] arma erguida, tratado como um ancião quase bíblico, um perfeito Africano" ${ }^{30}$, ou seja, em aparato militar.

\footnotetext{
${ }^{25}$ GOMES, Saúl António - op. cit., p. 269.

${ }^{26}$ PINA, Rui de - Chronica do Senhor Rey D. Affonso V... pp. 879-880.

${ }^{27}$ GOMES, Saúl António - op. cit., p. 270.

${ }^{28}$ Idem, ibidem.

${ }^{29}$ Idem, ibidem.

${ }^{30}$ GOMES, Saúl António - op.cit., p. 11.
} 
Figura 1: D. Afonso V [pormenor]. Fólio 13.

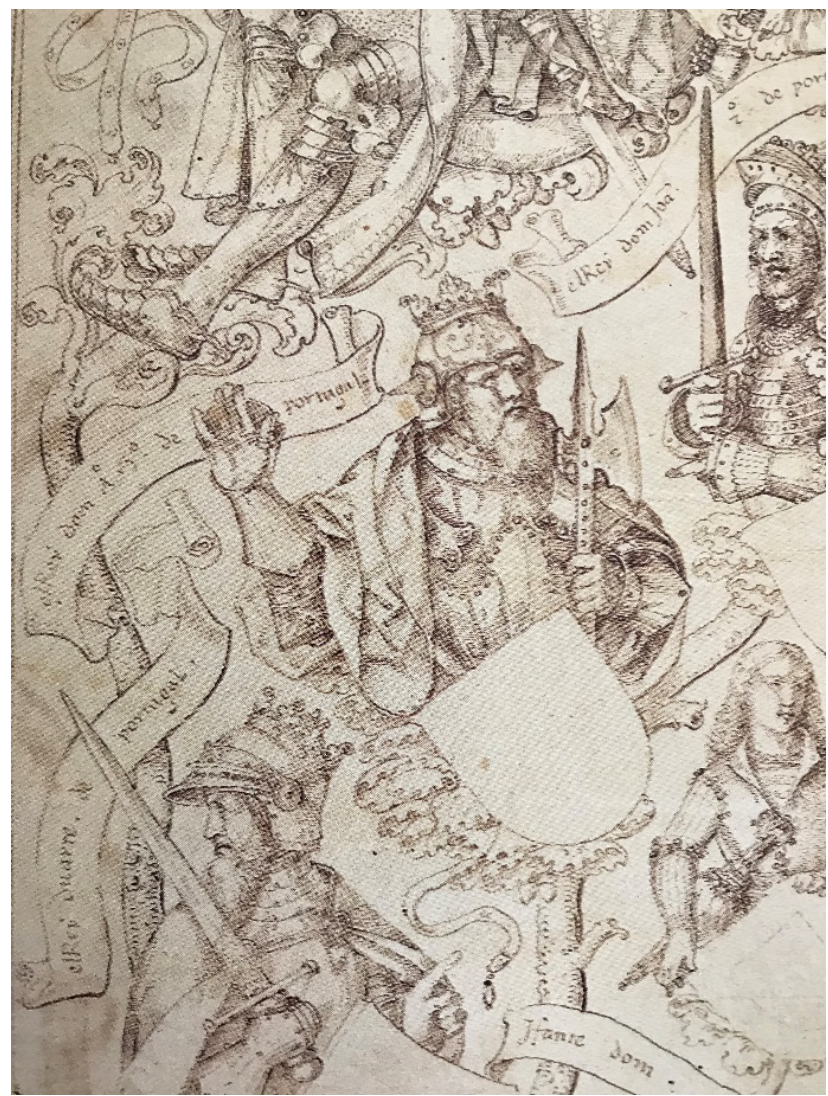

FONTE: HOLANDA, António de; BENING, Simão - A Genealogia do Infante Dom Fernando de Portugal. Introdução, notas, direção artística e gráfica de Martim de Albuquerque e João Paulo de Abreu e Lima. Porto - Lisboa: Banco de Portugal, 1984.

D. Afonso V é representado de arma em punho e com uma armadura corretamente colocada, verdadeira imagem de um cavaleiro. Carrega, contudo, uma coroa, símbolo da sua dignidade real provada no campo de batalha.

Esta representação perdurou no tempo, na medida em que, com exceção das iluminuras contemporâneas de el-rei ${ }^{31}$, se optou por mostrá-lo, pelo menos até aos séculos XVII e XVIII,

[...] em formato de busto, como patriarca e ancião, olvidando que esse homem faleceu aos 49 anos de idade, longe, portanto, mesmo à luz das concepções sobre a velhice desses tempos, da realidade" 32 . Estando a mencionada iluminura por concluir, é impossível compará-la com a descrição física legada por Rui de Pina, segundo a qual "foy ElRey Dom Afonso Princepe mais de grande que meaã estatura, e em todos eus membros bem feyto e muy proporcionado [...], teve ho rosto redondo, bem povoado de barba preta, e em todallas outras partes do corpo muyto cabeludo $[\ldots]^{33}$.

O pendor bélico associado às iconografias régias, como imagem de proteção dos seus súbditos, vinha já de períodos muito recuados. De resto, o último capítulo da Crónica de D. Afonso $V$ é bastante ilustrativo no que toca à imagem aguerrida do monarca que se pretendia

\footnotetext{
${ }^{31}$ Estilizadas em concordância com os modelos simbólicos caraterísticos das armarias tardo-medievais, em que o rei aparece como um jovem perfeito.

${ }^{32}$ GOMES, Saúl António - op. cit., p. 11.

${ }^{33}$ PINA, Rui de - Chronica do Senhor Rey D. Affonso V... p. 880.
} 
imortalizar: “[...] e por ser Pryncepe de muy alto e esforçado coraçam, foy sempre zellador de emprender cousas arduas, e prosseguyllas por armas como cavaleiro [...]"34 . Considero bastante curioso que imediatamente a seguir a este elogio das e às armas venha a afirmação "[...] mais que de entender como Rey no Regimento Civel e Polytico de Reynos" ${ }^{35}$. Qual seria a verdadeira intenção de Rui de Pina, ou do comitente do texto, ao incluir esta ideia? Será a simples expressão de um certo desinteresse medieval pelo campo político, em oposição ao respeito pela guerra? Ou será uma subtil crítica ao soberano, sobretudo se tivermos em consideração que a ação governativa do seu tio Infante D. Pedro tende a ser considerada superior à sua?

Uma questão idêntica pode ser levantada a respeito da asserção:

Foy Pryncepe de muy graciosa presença, grande humanydade, e doce conversação, mas foy em tanto estremo, que pera Rey superior nom foy muyto de louvar; porque com grande familiaridade que de sy, contra sua gravydade e Estado Real, a muytos dava [... $]^{36}$.

Terá esta descrição servido como uma crítica disfarçada de louvor à capacidade de governação de O Africano? Não esqueço que as crónicas obedeciam a formulações específicas, algumas decalcadas de hagiografias, pelo que não ignoro que tais afirmações podem apenas corresponder a construções frásicas indispensáveis a este tipo textual. Para melhor ilustrar esta ideia, segue em anexo um quadro, por mim elaborado, comparando a Crónica de D. Afonso $V$ e a Crónica de D. João II no que às feições, virtudes e costumes do soberano diz respeito.

Independentemente da intenção por trás destas palavras, o certo é que as medidas tomadas pelo soberano a nível político, sobretudo as relativas à guerra, são louvadas algumas linhas abaixo, sendo O Africano

\footnotetext{
tam confiado de seu saber, que com difyculdade queria estar per alheos conselhos se se contradiziam sua vontade, especialmente nas cousas da guerra dos Mouros, em cujo prosseguimento foy sempre tam aceso e inclinado, que acerca disso todo seu apetito lhe pareciam vivas rezooẽs ${ }^{37}$.
}

Atrevo-me a pensar que, em certa medida, as acometidas em África corresponderam à necessidade de imortalização de uma ideia guerreira da geração de Avis e do reino, bem ao gosto do Quattrocento. Se, do ponto de vista plástico, alguns autores afirmam que Portugal esteve sempre na cauda da Europa, aqui pode-se ver claramente que, a nível ideológico, este retângulo à beira mar plantado não ficou assim tão atrás.

Foi com o intuito de celebrar estas conquistas e de afirmar o seu poder que $\mathrm{O}$ Africano encomendou um conjunto de quatro tapeçarias, retratando a tomada de duas cidades do norte

\footnotetext{
${ }^{34}$ Idem, p. 881.

${ }^{35}$ Idem, ibidem.

${ }^{36}$ Idem, p. 880.

${ }^{37}$ Idem, p. 881.
} 
de África. Três das tapeçarias dizem respeito a Arzila - O desembarque em Arzila; O cerco a Arzila, $O$ assalto a Arzila - e apenas uma se reporta a Tânger - A entrada em Tânger.

Em O Desembarque em Arzila, segundo Inês Meira Araújo, estão retratados três episódios distintos numa mesma composição:

- A chegada do exército português, na ala esquerda da tapeçaria;

- O desembarque desastroso devido às condições do mar, o que levou ao naufrágio de parte das embarcações e à morte de alguns combatentes, na orla inferior da parte central da tapeçaria,

- A marcha da hoste real portuguesa para a urbe, de forma a estabelecer o arraial, na orla superior do centro da tapeçaria. Salienta-se que a orla esquerda é ocupada pela representação da cidade de Arzila, contando com alguns militares mouros ${ }^{38}$.

Figura 2: O Desembarque em Arzila, tapeçaria atribuída à oficina de Pasquier Grenier, Tournai (Bélgica), último quartel do século XV.

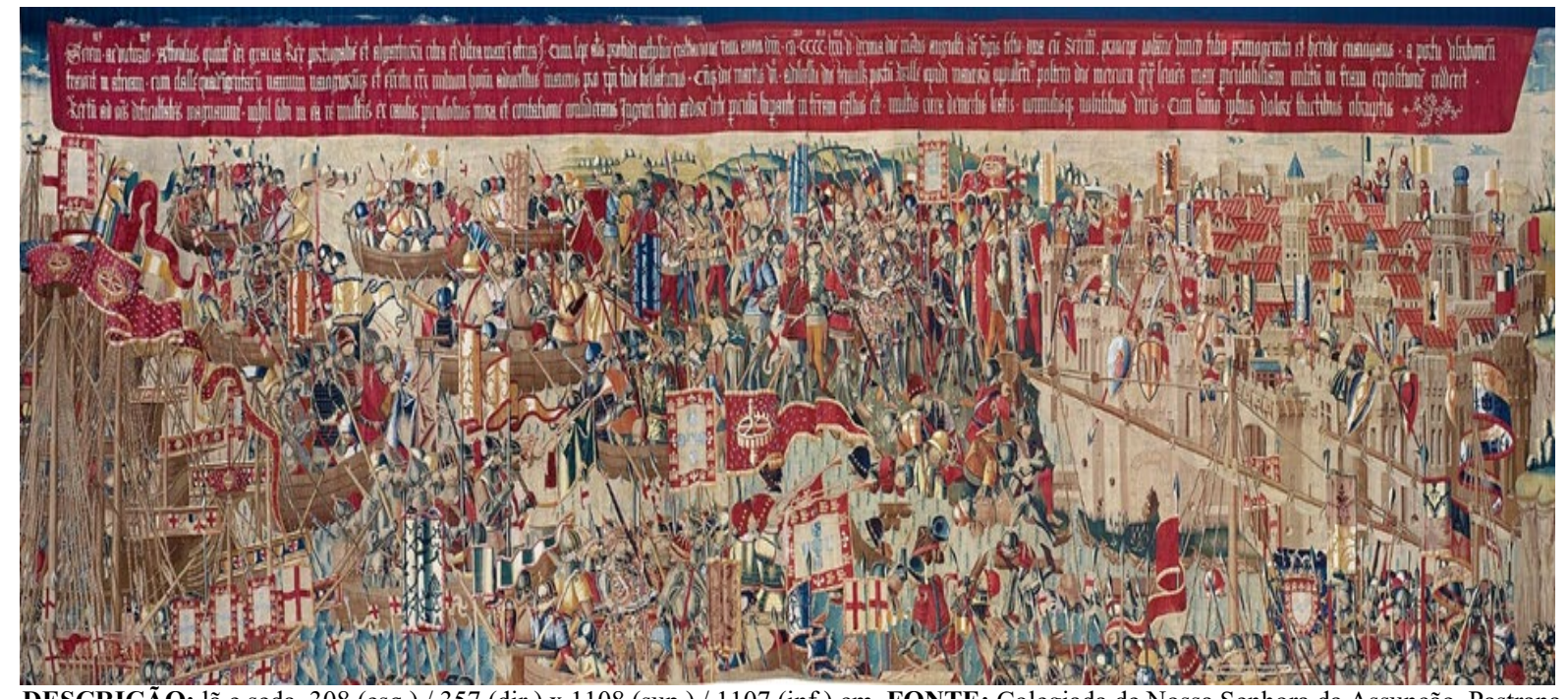

DESCRIÇÃO: lã e seda, 308 (esq.) / 357 (dir.) x 1108 (sup.) / 1107 (inf.) cm. FONTE: Colegiada de Nossa Senhora da Assunção, Pastrana (Guadalajara, Espanha); Wikimedia Commons.

Da esquerda para a direita podem-se ver: a chegada do exército português e o seu desembarque, bem como a marcha da hoste real portuguesa para a cidade.

Contrariamente à tapeçaria anterior, O Cerco a Arzila mostra somente um episódio, que o espectador observa a partir de terra. O plano de fundo é dominado pelos mastros e cestos de gávea dos navios lusitanos, vendo-se, num plano posterior, um arraial com um número alargado de combatentes ${ }^{39}$.

\footnotetext{
${ }^{38}$ ARAÚJO, Inês Filipa Meira - op. cit., p. 67.

${ }^{39}$ Idem, p. 70.
} 
Figura 3: $O$ Cerco a Arzila, tapeçaria atribuída à oficina de Pasquier Grenier, Tournai (Bélgica), último quartel do século XV.

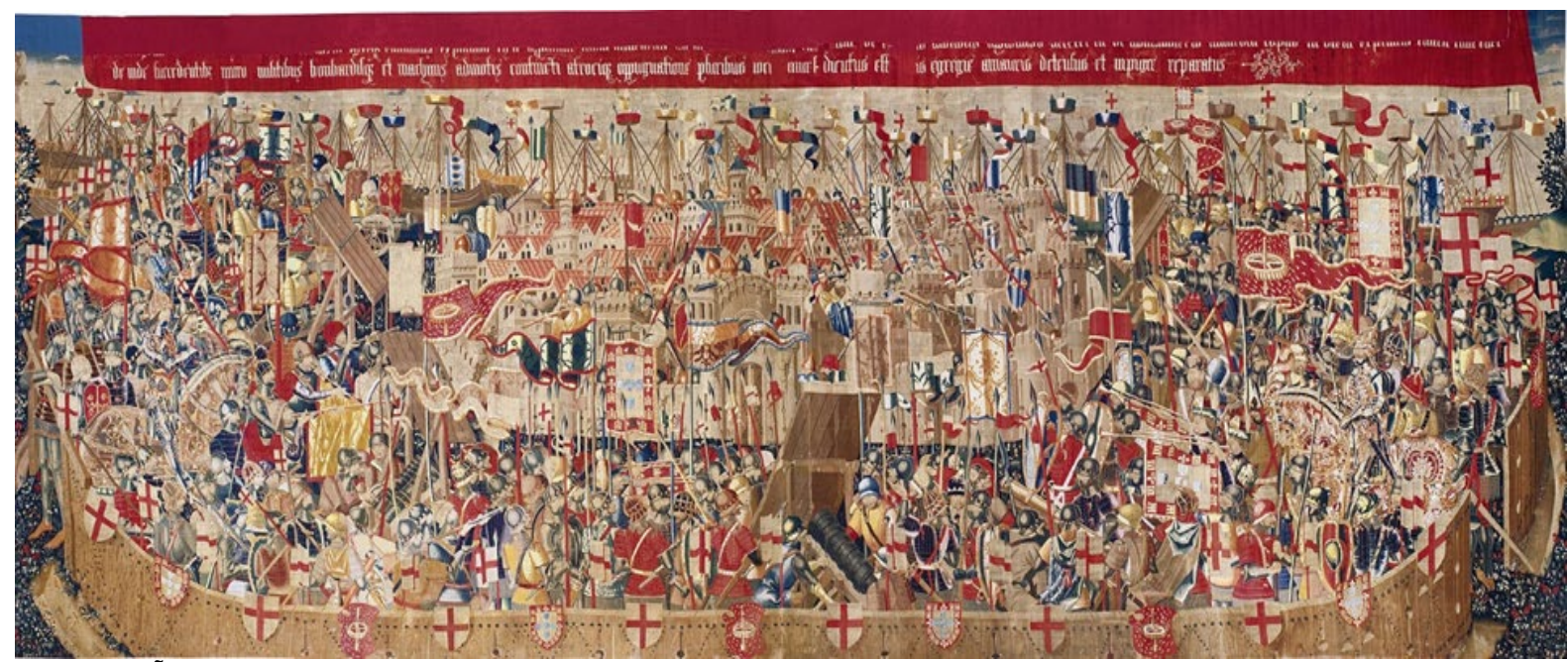

DESCRIÇÃO: lã e seda, 408 (esq.) / 442 (dir.) x 1108 (sup.) / 1178 (inf.) cm. FONTE: Colegiada de Nossa Senhora da Assunção, Pastrana (Guadalajara, Espanha); Wikimedia Commons.

O plano de fundo é dominado pelos mastros e cestos de gávea dos navios portugueses, vendo-se, num plano posterior, um grande exército.

O Assalto a Arzila é uma tapeçaria dominada por dois elementos principais que se misturam entre si. Em primeiro plano surge a hoste portuguesa atacando a urbe e, em segundo plano, uma fortificação, sobre a qual alguns guerreiros lusos sobem com o auxílio de escadas. Em último plano estão representados os supramencionados mastros portugueses, que, neste momento, impedem ou a fuga do inimigo por mar ou o seu pedido de reforços. As laterais são dominadas pela figura do soberano e do príncipe herdeiro ${ }^{40}$.

\footnotetext{
${ }^{40}$ Idem, p. 73.
} 
Figura 4: O Assalto a Arzila, tapeçaria atribuída à oficina de Pasquier Grenier, Tournai (Bélgica), último quartel do século XV.

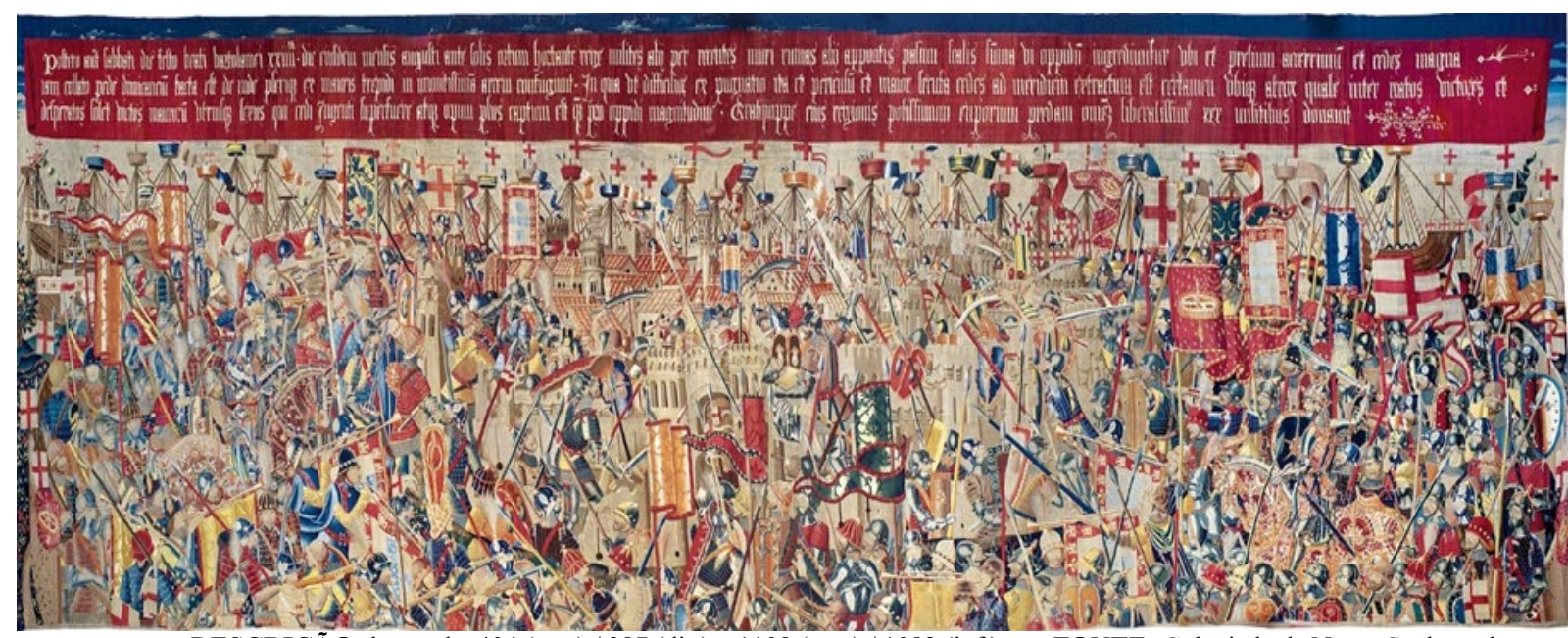

DESCRIÇÃ̃: lã e seda, 404 (esq.) / 387 (dir.) x 1108 (sup.) / 1082 (inf.) cm. FONTE: Colegiada de Nossa Senhora da

Assunção, Pastrana (Guadalajara, Espanha); Wikimedia Commons.

Em primeiro plano surgem as tropas portuguesas atacando a praça e, em segundo plano, uma fortificação muçulmana, sobre a qual alguns guerreiros sobem com o auxílio de escadas. Em último plano estão representados mais mastros portugueses, impedindo a fuga do inimigo por mar ou o seu pedido de reforços. Nas laterais encontramos as figuras do soberano e do príncipe herdeiro.

Tal como O Desembarque em Arzila, A Entrada em Tânger conta três episódios numa só composição:

- À direita vê-se a população muçulmana a abandonar a praça de Tânger;

- Ao centro está representada a fortaleza de Tânger, já vazia. Araújo ressalva que a cidade parece intacta e não danificada pelos seus próprios habitantes, como narra Rui de Pina,

- A chegada de uma hoste portuguesa triunfante é apresentada na orla esquerda da tapeçaria. 
Figura 5: A Entrada em Tânger, tapeçaria atribuída à oficina de Pasquier Grenier, Tournai (Bélgica), último quartel do século XV.

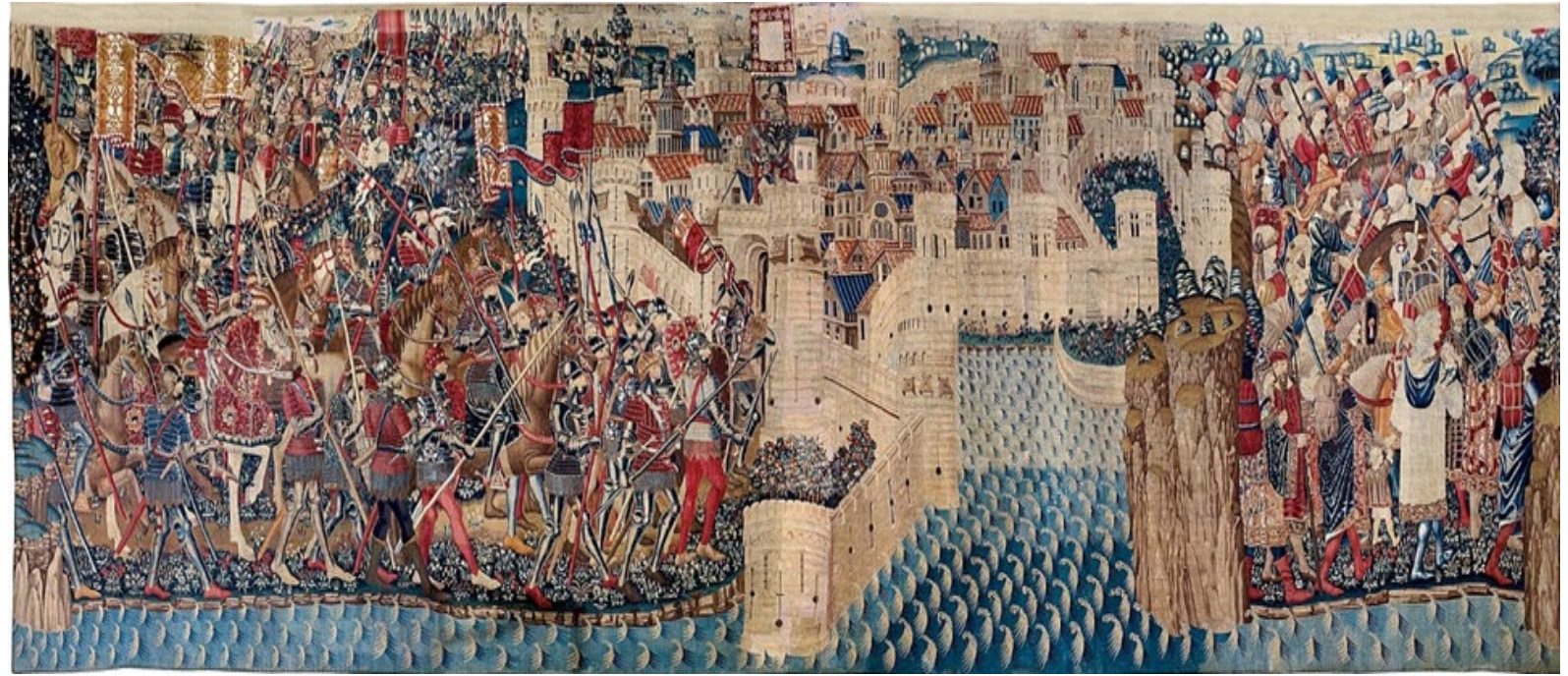

DESCRIÇÃO: lã e seda, 404 (esq.) / 387 (dir.) x 1108 (sup.) / 1082 (inf.) cm. FONTE: Colegiada de Nossa Senhora da Assunção, Pastrana (Guadalajara, Espanha); Wikimedia Commons.

Da esquerda para a direita, vêem-se a população muçulmana a abandonar a praça de Tânger, a fortaleza de Tânger vazia e a chegada de uma hoste portuguesa vitoriosa.

As Tapeçarias de Pastrana, hoje atribuídas, graças a Reinaldo dos Santos, à oficina flamenga de Pasquier Grenier ${ }^{41}$ e que seguem com relativo rigor o Estilo de Tournai ${ }^{42}$, evocam uma temática militar, de fácil e direta compreensão, e de um modo não alegórico. Refletem, portanto, um acontecimento contemporâneo à sua manufatura, algo que Araújo considera pouco usual levando em consideração as peças que chegaram até aos dias de hoje.

A dimensão alargada das peças permitia aos frequentadores destes lugares ter um vislumbre do mundo ali representado, como se revivessem naquele momento o acontecimento que se desenrolava ao longo das paredes daquela divisão ou permitindo-lhes materializar em imagem o que liam ou ouviam nos romances. Era, pois, uma experiência vicarial, quase realista ${ }^{43}$.

Sabe-se que o interesse do monarca português pela arte da tapeçaria vinha já de períodos mais recuados, visto que, ainda em 1452, há registos de um escudeiro de D. Afonso V se ter dirigido a Tournai e a Lille em busca destes objetos decorativos.

A falta de documentação sobre a encomenda ou elaboração das Tapeçarias de Pastrana, aliada à sua integração no gosto europeu pela tapeçaria na segunda metade do século XV,

\footnotetext{
${ }^{41}$ Pasquier Grenier, cuja atividade se estendeu entre 1447 e 1493 , mostra-se como o principal fornecedor de tapeçarias para a Casa da Borgonha, e, consequentemente, uma das figuras principais da tapeçaria do período tardomedieval. Salienta-se que este não era um tapeceiro, mas sim um comerciante ligado a algumas tapeçarias produzidas na época, podendo não ter sido o responsável pela elaboração dos panos, mas sim pelo trato do negócio. ${ }^{42}$ Caraterizado por superfícies muito preenchidas e bem decoradas com figuras expressivas, juntas e interligadas, não deixando quase espaços vazios, com indumentária e armamento muito pormenorizados e adornados. A paisagem e os fundos eram escassos ou inexistentes, ainda que contassem com flores e ervas detalhadas. A grande preocupação com a minúcia e o detalhe refletem, na minha ótica, alguma influência flamenga.

${ }^{43}$ ARAÚJO, Inês Filipa Meira - op. cit., p. 32.
} 
permite balizá-las num alargado espectro temporal: de 1471, ano da conquista das praças magrebinas, a 1481, ano da morte de D. Afonso V. Se alguns autores, como Afonso de Dornelas e Eustoquio García Merchante, entendem que as tapeçarias poderão ter sido encomendadas com o objetivo de serem oferecidas a Castela, visando conseguir o apaziguar das relações entre os dois reinos ibéricos, outros consideram que, num período posterior à Batalha de Toro, O Africano, enfraquecido e amargurado, terá solicitado a manufatura destes objetos decorativos como forma de propagandear os feitos dos seus tempos áureos ${ }^{44}$. Embora Araújo pareça rejeitar esta cronologia mais tardia, devido ao facto de a coroa portuguesa passar por um período de dificuldades económicas, e de alguns historiadores considerarem que seria já D. João II a governar o reino, não me parece que se possa excluir em absoluto esta tese, na medida em que os fins propagandísticos da encomenda das Tapeçarias de Pastrana parecem ser bastante certos. De resto, o facto de as tapeçarias não conterem fios de urdidura em ouro ou prata parece apontar para uma tentativa de as realizar de um modo o menos dispendioso possível, quiçá devido a um tempo de crise.

Para a elaboração de uma tapeçaria era primeiro realizado um esboço em cartão, um pequeno desenho que serviria de guia à iconografia a representar. Estes cartões podiam ser fornecidos pelo futuro proprietário, caso a encomenda se prendesse com uma temática em específico, ou resultar de adaptações de desenhos habitualmente trabalhados na oficina escolhida. Alguns autores atribuem a autoria dos cartões referentes às Tapeçarias de Pastrana a Nuno Gonçalves, cuja oficina realizou os Painéis de São Vicente de Fora, uma vez que ambas as peças denunciam processos criativos comuns e que Gonçalves foi nomeado pintor régio de O Africano a partir de 1450. Efetivamente, uma carta régia de 20 de julho de 1450 apresenta a quantia anual de “(...) 12\$000 reais brancos [como ordenado de Nuno Gonçalves], uma segunda carta régia de D. Afonso V, de 6 de abril de 1452, (...) acrescenta $3 \$ 432$ reais ao ordenado do pintor (...)"45. A avultada soma de dinheiro que Nuno Gonçalves recebia anualmente concorre para a ideia de que, ao longo do Quattrocento, se passou de uma conceção medieval de artesão para a ideia do artista enquanto trabalhador intelectual, que se distinguia pelo seu engenho.

Araújo ressalva, contudo, que atribuição dos sobreditos cartões a Nuno Gonçalves poderá ter resultado da vontade de criar em Portugal uma escola artística ao nível da espanhola ou da flamenga, ou seja, da necessidade de enaltecer um dos grandes artistas do tardogótico português. Ainda que existam caraterísticas que aproximem ambas as obras de arte, o conhecimento em relação à estética portuguesa do século XV é muito escasso, pelo que, segundo a mesma autora, não se deve excluir a possibilidade de existirem no reino outros

\footnotetext{
${ }^{44}$ Idem.

${ }^{45}$ GUSMÃO, Adriano de - Nuno Gonçalves. Lisboa: Artis, 1958.
} 
artistas capazes de conceber este tipo de composições. Em verdade, à medida que a centúria avançava, os tapeceiros iam-se aproximando cada vez mais do mundo da pintura de cavalete e a construção de algumas tapeçarias ia-se tornando idêntica à pintura retabular ${ }^{46}$.

A opção pela representação das conquistas marroquinas parece ser a que mais se adequa aos objetivos legitimários de D. Afonso V. Mostravam a capacidade militar do reino, mas, sobretudo, destacavam a imagem do monarca como chefe militar de exceção e como líder incontestado do seu povo. Era, como já referi, um rei-guerreiro, o maior cavaleiro entre os cavaleiros, que não receava deixar o seu reino para combater os muçulmanos, pelo bem da cristandade e do seu povo ${ }^{47}$.

Este ideário está patente na representação bem marcada do monarca: “[...] montado, com armadura completa e decorada, carregando um bastão de comando, ou levantando a espada, símbolo supremo do pensamento cavaleiresco medieval"48. Assim, as Tapeçarias de Pastrana plastificam tanto o acontecimento histórico do cerco, conquista e tomada das praças de Arzila e Tânger, quanto o retrato de um rei majestático.

De pé, no batel que o transporta para as areias de Arzila ou montado na entrada triunfal na cidade, aí vemos as imagens de uma identidade que contêm tanto de retratismo épico e real quanto de réplica de um monarca que, agora, se faz projectar a si mesmo como enigma, lumínico e faustoso, como um verdadeiro condottiere depois da batalha ganha, como um comandante supremo de um poderoso e vastíssimo exército convencido da sua inquebrantável superioridade militar ${ }^{49}$.

O próprio Rui de Pina apresentou O Africano como um majestoso rei cavaleiro, como se pode ler na seguinte passagem: “[...] ElRey posto em hum cavalo Sezeliano, armado e acobertado com sua espada nua na maaõ, mandou cometer a Villa com alguma mostrança de combate [...]"

Segundo Federico Revilla, à imagem do cavaleiro corresponde um

ideal medieval, que no sólo consiste en una superioridade guerrera por la posesión del caballo, sino además conlleva unas exigências morales: protección al débil, valentia en el combate, etc. El caballero simboliza el espíritu domeñando la materia, de igual modo que aquél rige su caballo. La violencia queda matizada por finalidades altruistas $[\ldots]^{51}$.

Já à figura do rei estão inerentes as funções de

defender las manifestaciones del mismo que son el orden moral, la paz, la justicia, la verdade o el bien [...] la palabra del rey establece la justicia. A menudo es también legislador. En el orden material, compete el rey defender al Pueblo contra los males ${ }^{52}$.

\footnotetext{
${ }^{46}$ ARAÚJO, Inês Filipa Meira - op. cit.

${ }^{47}$ Idem.

${ }^{48}$ Idem, p. 61

${ }^{49}$ GOMES, Saúl António - op. cit., p. 10.

${ }^{50}$ PINA, Rui de - Chronica do Senhor Rey D. Affonso V... p. 776.

${ }^{51}$ REVILLA, Federico - Diccionario de Iconografía. Madrid: Ediciones Cátedra, 1990. p. 71.

${ }^{52}$ Idem, p. 321.
} 
De facto, Rui de Pina desenha D. Afonso V como o verdadeiro arquétipo da justiça, afirmando que "especialmente nas [questões] da justiça que tocavam contra grandes pessoas, as quaaes mais folgava de dessymullar ou temperar brandamente, que exucutallas com rigor, e cresse que isto procedia de sua grande humanydade, e assy por assessego de seus Reinos" ${ }^{\text {. }}$.

Todavia, se nas Tapeçarias de Pastrana somos confrontados com um soberano guerreiro, ladeado de símbolos de pendor bélico, nos Painéis de São Vicente de Fora podemos admirar uma realidade bastante diferente, mas que não deixa de se relacionar com a anterior. Neles está patente uma postura devocional profunda face ao mártir, a quem o próprio D. Afonso Henriques tanto cultuava. $\mathrm{O}$ respeito face às figuras sagradas era uma caraterística imprescindível para se ser um bom governante, ideia que motivou Rui de Pina a deixar por escrito que

foy [O Africano] Pryncepe muy Catolico e amigo de Deos, e mui fervente na fée, ouvia continuada e muy devotamente os Offycios Divinos, e polla moor sem grandes pompas e cirimonias, deleitavasse com homens honestos Relligiosos e de bom viver, em ele apartado muytas vezes ao seu modo conversava $[\ldots]^{54}$.

O cuidado religioso era outra das caraterísticas preponderantes de algumas das iconografias régias, atribuindo-se à sua figura funções sacerdotais ${ }^{55}$.

Figura 6: Painéis de São Vicente de Fora, atribuídos a Nuno Gonçalves. Portugal, último quartel do século XV.

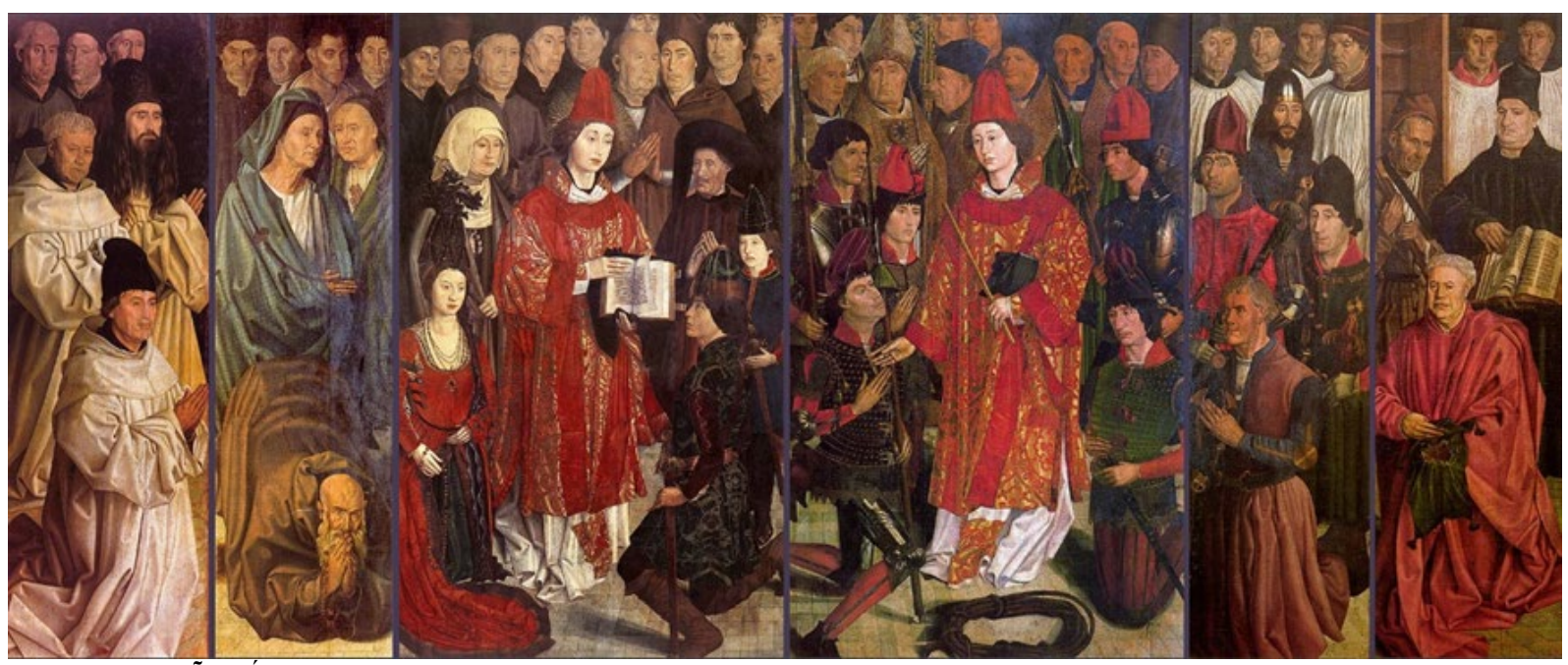

DESCRIÇÃO: Óleo e têmpera sobre madeira. FONTE: Museu Nacional de Arte Antiga, Lisboa (Portugal); Wikimedia Commons.

\footnotetext{
${ }^{53}$ PINA, Rui de - Chronica do Senhor Rey D. Affonso V... p. 880.

${ }^{54}$ Idem, p. 881.

${ }^{55}$ REVILLA, Federico - op. cit., p. 321.
} 

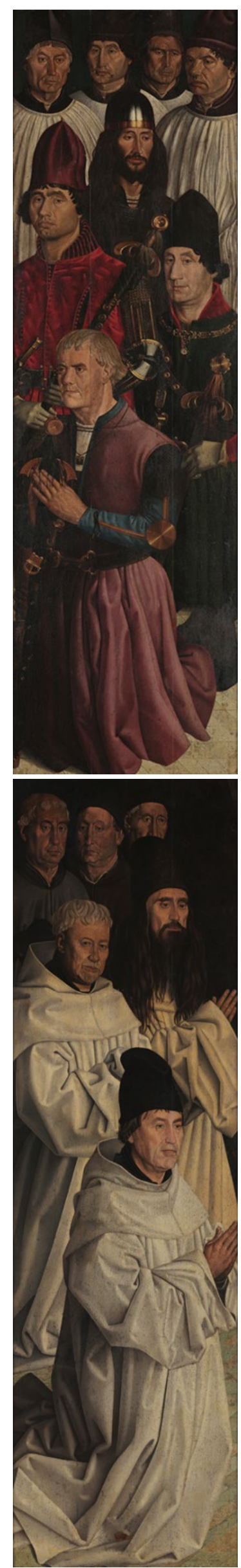

Figura 7: Painel dos Cavaleiros (à esq.).

FONTE: Museu Nacional de Arte Antiga, Lisboa (Portugal);

Wikimedia Commons.

Figura 8: Painel da Relíquia (à dir.). FONTE: Museu Nacional de Arte Antiga, Lisboa

(Portugal); Wikimedia Commons.

Figura 9: Painel dos Frades (à esq.).

FONTE: Museu Nacional de Arte Antiga, Lisboa (Portugal);

Wikimedia Commons.

Figura 8: Painel dos Pescadores (à dir.). FONTE: Museu Nacional de Arte Antiga, Lisboa (Portugal); Wikimedia Commons.
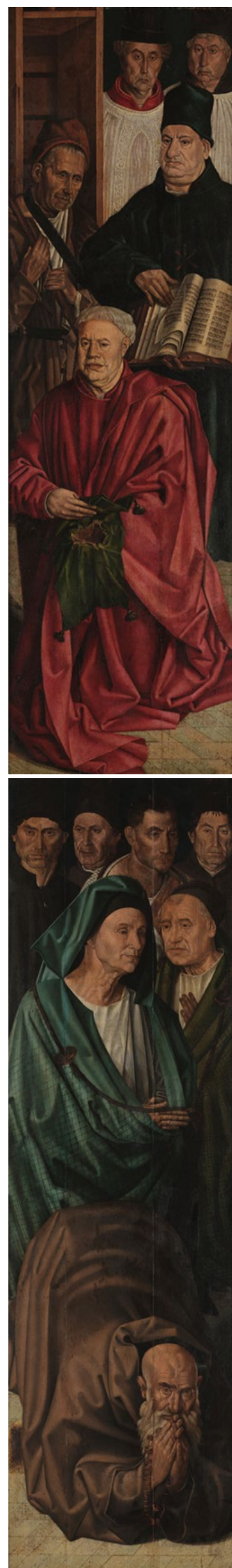
Figura 11: Painel do Infante.

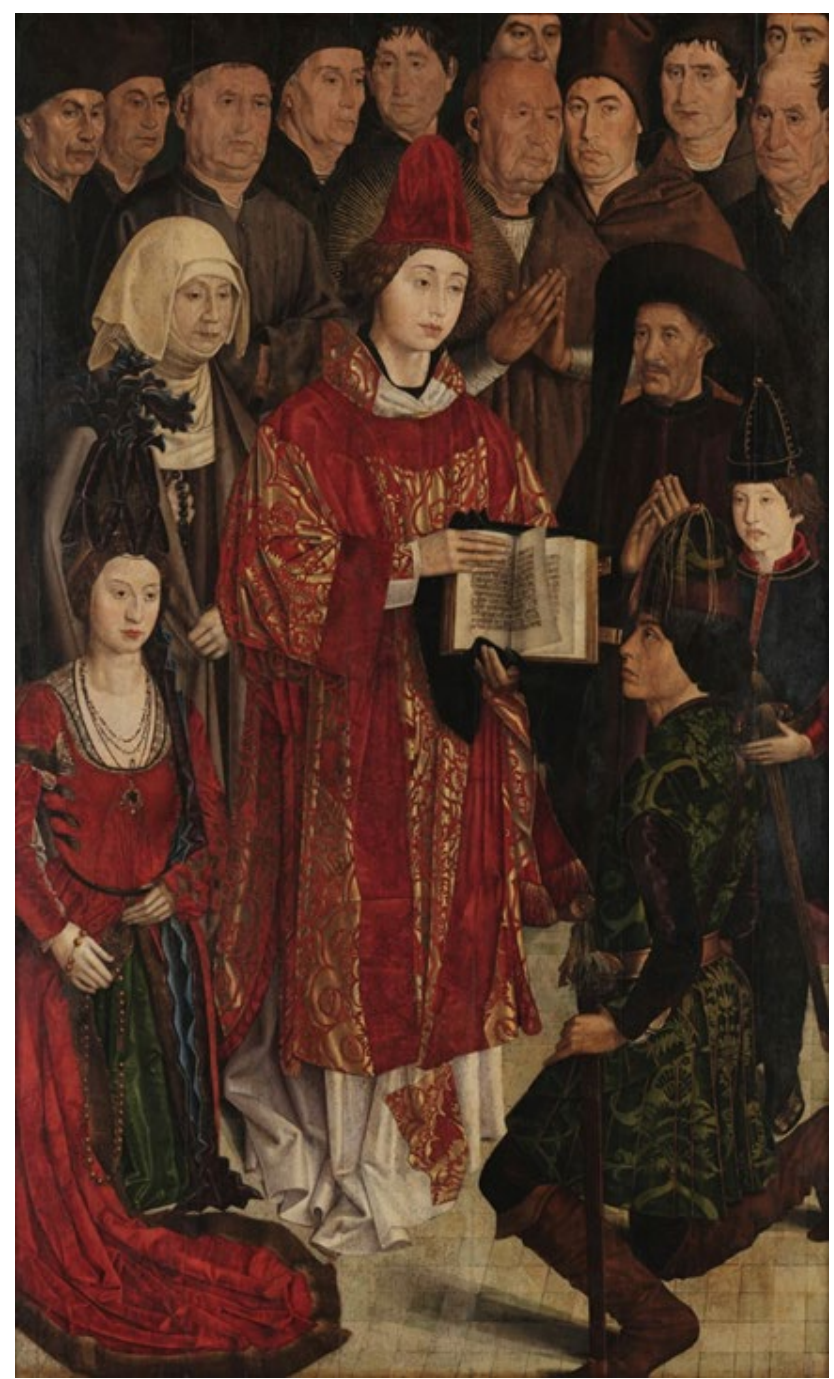

FONTE: Museu Nacional de Arte Antiga, Lisboa (Portugal); Wikimedia Commons.

A ideia, defendida por Dagoberto Mark1, segundo a qual, de acordo com a Chronica dos Feitos da Guiné, D. Henrique não poderia ser a figura masculina com o chapéu, por ser descrito como "[...] homem de carnadura grossa, e de largos e fortes membros [...]. Sua presença, do primeyro esgoardo, aos nom usados era temerosa [...]"56 parece ignorar o facto de que as crónicas eram redigidas visando enaltecer a glória dos retratados. Por outro lado, também o aspeto calmo e sereno do homem do chapeirão pode não representar o verdadeiro caráter de D. Henrique, uma vez que, desde os finais do século XIV, a arte entendia a serenidade nas feições como uma caraterística dos bons governantes, à maneira romana. Além do mais, O Navegador havia já falecido ao tempo da elaboração dos Painéis, pelo que se tentava pintá-lo para a eternidade, ou seja, como alguém que já havia transcendido o mundo terreno.

\footnotetext{
${ }^{56}$ ZURARA, Gomes Eanes de - Chronica dos Feitos da Guiné. In MARKL, Dagoberto L. - O Retábulo de S. Vicente da Sé de Lisboa e os Documentos. Lisboa: Editorial Caminho, agosto de 1988. p. 111.
} 
Figura 12: Painel do Arcebispo.

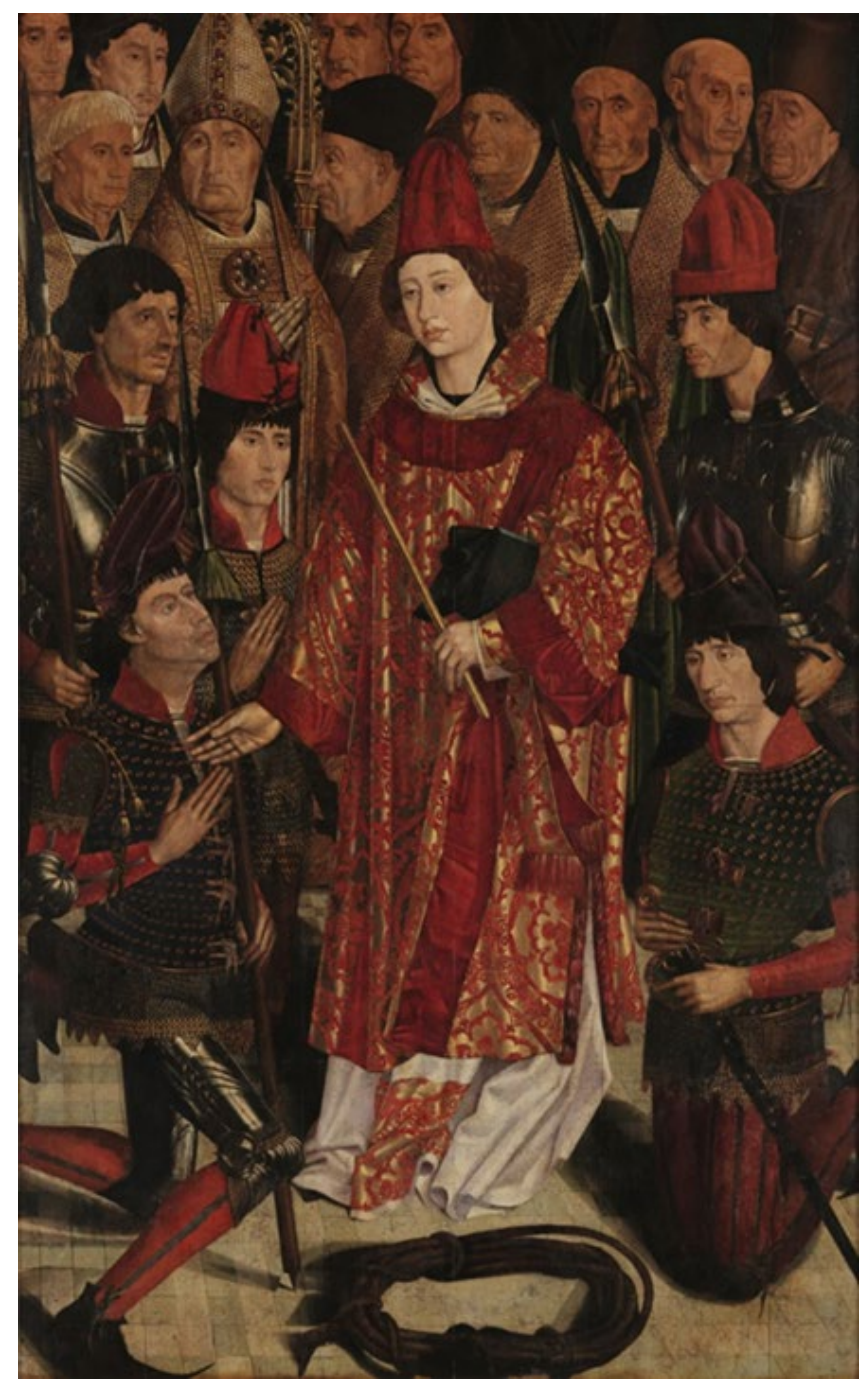

FONTE: Museu Nacional de Arte Antiga, Lisboa (Portugal); Wikimedia Commons.

O facto de São Vicente não aparecer, em nenhum dos painéis, representado com os seus atributos iconográficos tradicionais levou alguns autores a especularem sobre a possibilidade de a figura central do políptico ser, ao invés do santo diácono, o Infante D. Fernando. Contudo, estudos posteriores refutam esta hipótese.

Embora atribuição do políptico de veneração a São Vicente a Nuno Gonçalves pareça certa para a maioria dos historiadores da arte, a verdade é que "[...] um retábulo ${ }^{57}$ com a grandiosidade que se advinha para o de S. Vicente exigiria o esforço conjunto de muitos artífices - entalhadores, carpinteiros, prateiros [...], escultores, pintores [...]"58. Deve-se procurar desconstruir o mito do artista solitário, ainda que tendo em conta que, para artistas com um temperamento mais complicado essa ideia fosse verdadeira. O momento de abandono

\footnotetext{
${ }^{57}$ Um retábulo é uma estrutura de madeira, mármore ou de outro material, com lavores, que fica por trás ou por cima do altar e que, normalmente, encerra um ou mais painéis pintados ou em relevo.

${ }^{58}$ MARKL, Dagoberto L. - op. cit., p. 217.
} 
das oficinas de tradição medieval variou de região para região, mas estima-se que se tenha iniciado em Itália no século XVI e chegado a Portugal bastante mais tarde. A ideia do artista-génio, que trabalha sozinho e em completo isolamento, é um conceito criado a posteriori, no século XIX.

As representações da geração de Avis neste políptico são mais cortesãs do que bélicas, bem à moda da cronologia em que se inserem. Francisco de Holanda, em Da Pintura Antiga, defende que Nuno Gonçalves imitou os pintores italianos no naturalismo, no trabalho do retrato e no tratamento racional do panejamento e do espaço, merecendo por isso ser recordado ${ }^{59}$.

No momento em que realizou este políptico, Nuno Gonçalves solucionou os problemas de representação pictórica do espaço em concordância com os seus contemporâneos. De facto, o caráter real do espaço foi uma das grandes preocupações dos pintores deste período, só sendo ultrapassada com as primeiras experiências maneiristas. No entanto, o autor dos Painéis de São Vicente de Fora foi, segundo Adriano de Gusmão, "rudimentar na perspectiva linear, na perspectiva aérea [...] [foi] um arcaico." 60 . O autor parece considerar que este desprezo pelas novas perspetivas se deveu a uma falha do artista, porém, considero que existiu uma miríade de possibilidades para a pintura do século XV, e que nenhuma deve ser desmerecida face às outras. As inovações e aprendizagens destes homens do gótico internacional são díspares e aplicadas de diferentes maneiras, refletindo a conjuntura social e política em que se inserem e, até mesmo, a própria forma de criar do artista. Ainda que os seus objetivos pudessem ser idênticos, as formas de lá chegar eram muitíssimo variadas. Em verdade, "Nuno Gonçalves não se importou com paisagens de composição. Entrou no campo da psicologia, no íntimo das personagens, sem se preocupar com as perspetivas linear e aéreas" ${ }^{\prime 61}$.

Também na análise do tratamento dos rostos Adriano de Gusmão sentiu necessidade de comparar Nuno Gonçalves e os seus contemporâneos em Itália, ao afirmar que, se em Piero della Francesca se nota “[...] a constância da impersonalidade das suas majestosas figuras. Em Nuno Gonçalves [...] [se acusa] a constância da extrema caracterização dos seus modelos"62. Não me parece demais relembrar que, se mesmo em Itália não existia uma escola única de pintura, sendo, por exemplo, a pintura florentina muito diferente da veneziana, a confrontação entre um artista português e um italiano reflete um entendimento da história de arte já um pouco ultrapassado, caraterístico de uma obra com mais de meio século. De facto, talvez mesmo a

\footnotetext{
${ }^{59}$ HOLANDA, Francisco de - Da Pintura Antiga. In FRANCO, José Eduardo; FIOLHAIS, Carlos (dir.) Primeiros Tratados de Pintura de MONTEIRO, Patrícia; SERRÃO, Vítor (coord.). "Obras pioneiras da cultura portuguesa, vol. 12”. Lisboa: Círculo de Leitores, 2019. pp. 77-283.

${ }^{60}$ GUSMÃO, Adriano de - op. cit., p. 13.

${ }^{61}$ NEGREIROS, José Almada de - Almada. Os Painéis, a Geometria e Tudo. As entrevistas com António Valdemar. Prefácio de José Manuel dos Santos. Porto: Assírio \& Alvim, setembro de 2015. p. 173.

${ }^{62}$ GUSMÃO, Adriano de - op. cit., p. 12.
} 
busca por uma escola portuguesa ao nível das dos restantes países europeus não seja a maneira mais correta de olhar para estas questões.

Para Almada Negreiros, a quem os Painéis levaram da pintura para a história, o autor do políptico de veneração a São Vicente impunha-se perante as obras dos outros grandes artistas do século XV devido a:

- Estabilidade da pintura;

- Serenidade da manufatura;

- Presença individual de cada um dos seus personagens,

- Extrema concordância entre o desenho e o material utilizado ${ }^{63}$.

São Vicente, diácono, muito afamado entre os mártires espanhóis, foi condenado à morte em Valência, aquando da perseguição de Diocleciano, tendo padecido com valentia inúmeras torturas, entre elas ser queimado numa grelha. "Desde os tempos primitivos, os cristãos invocavam os mortos, especialmente, aos seus parentes íntimos, nas suas orações; este costume estendeu-se à invocação dos mártires, o qual eventualmente se sobrepôs ao primeiro" ${ }^{64}$. O martírio pressupunha uma identificação com Cristo, pelo que "[...] se considerase al mártir como cristiano perfecto, por cuanto había reproducido el acto salvador del proprio Cristo dando su vida" ${ }^{\circ 5}$.

Embora as narrativas da paixão de São Vicente devam mais à lenda do que à história, fixaram, desde cedo, os atributos da sua iconografia ${ }^{66}$ :

- A dalmática e o evangelho, símbolos da sua condição de diácono;

- O cavalete, a grelha e os garfos de ferro, instrumentos do seu sacrifício,

- A mó, o barco, “[...] lugar de seguridad, que permite atravesar indemne los perigos [...]. En la terminología cristiana, la «barca de Pedro» es la Iglesia, que conduce a los fieles a

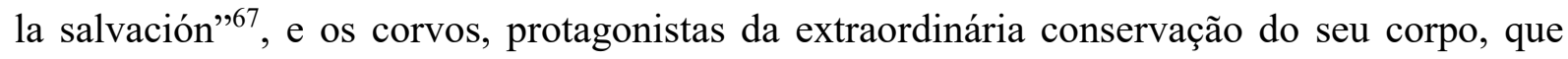
regressou a terra depois de lançado ao mar.

Resta, ainda, a palma, que, segundo Revilla, “en cuanto atributo común de los mártires - el que más facilmente permite identificarles como tales - une estas significaciones: el mártir ha obtenido la suprema victoria y com ella la vida eterna" ${ }^{98}$. A palmeira é uma árvore muito resistente,

\footnotetext{
${ }^{63}$ NEGREIROS, José Almada de - op. cit.

${ }^{64}$ ATTWATER, Donald - Dicionário de Santos. Trad. de Jorge Pinheiro. Mem Martins: Publicações EuropaAmérica, 1965. p. 10.

${ }^{65}$ REVILLA, Federico - op. cit., pp. 249-250.

${ }^{66}$ PICOITO, Pedro; VICENTE, Filipe Nunes; JORGE, Luís M. - A nau e os corvos: São Vicente e as armas de Lisboa. [s.1.]: Declínio e Queda, 2013.

(consultado em 17.11.2019).

${ }^{67}$ REVILLA, Federico - op. cit., p. 58.

${ }^{68}$ Idem, p. 288.
} 
pelo que, ao ser colocado um peso na sua copa, ela não cede, apenas se curva até ao lado contrário. Por não se dobrar perante nada, passou a ser utilizada como alegoria para o bom cristão - especialmente tendo em conta o episódio bíblico que junta Cristo e uma destas árvores ${ }^{69}-$ ou do justo $^{70}$.

Esa asociación entre mártir y palma llegó a ser determinante. La Congregatio pro Sacri Ritibus et Caeremoniis de 1688 llegó a afirmar que el encontrar una palma representada en una tumba de los primeros cristianos era prueba fehaciente de que escondía la tumba de un mártir. Nada más lejos de la realidad $[\ldots]^{71}$.

Mas, são inúmeros os exemplos em iconografia medieval de mártires carregando palmas como atributo. Sumariamente, cada mártir tem um ou mais atributos particulares habitualmente os instrumentos do seu suplício -, mas a folha da palmeira e a auréola são comuns a todos ${ }^{72}$. A palma

es el símbolo por antonomasia de los mártires, cuya iconografía podemos rastrear en los premios que se otorgaban en las competiciones de muy diversa índole. Se convierte así, es un símbolo supra-martirial; pero también en el árbol del Paraíso, elegido por Cristo, y una vía en sí misma para llegar al cielo ${ }^{73}$.

A presença de uma capela dedicada a este mártir na Sé de Lisboa parece dever-se à crença de que parte das suas relíquias estariam guardadas em tal cidade. Não obstante, “[...] o facto de o santo diácono não figurar representado com os tradicionais atributos iconográficos, [...] bem como a circunstância de se representar um rolo de cordas cuja significação é imediatamente ambígua, deu origem a diversas teses interpretativas, designadamente à da correspondência da figura não com São Vicente, mas antes com o mártir D. Fernando, cujos ossos se procuravam resgatar nas campanhas africanas" ${ }^{, 74}$. Fausto Martins refuta esta tese, na medida em que, para o políptico representar esse tal sufrágio solene em memória do Infante D. Fernando, teria de perpassar em todo ele uma aura de luto e de pranto, o que não corresponde à realidade apresentada, muito mais colorida, ainda que cerimoniosa. Se o sentimento de culpa perante o trágico destino do Infante parece poder motivar a elaboração de um políptico que visasse a beatificação de tal figura, a verdade é que não se divisa qualquer sinal de cerimónia fúnebre na representação dos Painéis ${ }^{75}$.

\footnotetext{
${ }^{69}$ Durante a subida ao Egito, Maria quis descansar à sombra de uma palmeira e, vendo os seus frutos, pediu a José que lhe conseguisse um. Por estarem muito alto, São José considerou que essa seria uma tarefa impossível, porém, Cristo, ainda menino, pediu à palmeira que se dobrasse, e ela assim o fez.

${ }^{70}$ LACALLE, Ana Valtierra - "La Palmera y la Palma. Adaptación Medieval de una Antigua Iconografía". Revista Digital de Iconografia Medieval. [Em Linha] Madrid: Universidad Complutense. N. 17 (2017) pp. 105-124.

${ }^{71}$ Idem, p. 113.

${ }^{72}$ LEMAÎTRE, Nicole; QUINSON, Marie-Thérèse; SOT, Véronique-Dicionário Cultural do Cristianismo. Trad. de José David Antunes. Lisboa: Publicações Dom Quixote, 1999.

${ }^{73}$ LACALLE, Ana Valtierra - op. cit., p. 117.

${ }^{74}$ RODRIGUES, Dalila - As tapeçarias de Pastrana e os painéis de São Vicente. Legado artístico e memória simbólica do reinado de Afonso $V$. In HENRIQUES, Ana de Castro (coord.) - op. cit., p. 31.

${ }^{75}$ MARTINS, Fausto S. - "Aspetos Polémicos dos Painéis de São Vicente: Ritual e Iconografia". Revista da Faculdade de Letras: Ciências e Técnicas do Património. [Em Linha] Porto: Faculdade de Letras - Universidade do Porto. Vol. 2 (2003) pp. 267-290.
} 


\section{Conclusão}

Do exposto se conclui que O Africano não tentou construir apenas uma imagem de si mesmo, mas sim duas. Com as Tapeçarias de Pastrana, procurou fazer-se representar como um rei guerreiro, capaz de avançar pelo campo de batalha ao lado de qualquer um dos seus súbditos, numa clara concordância com o ideário medieval. Nos Painéis de São Vicente de Fora, vê-se um rei mais solene, mais próximo até dos ideais neoplatónicos italianos e do entendimento do espaço dos maneiristas posteriores. Resta, contudo, estudar a receção que ambas estas obras tiveram no seio dos cânones artísticos medievais.

As duas encomendas articulam-se na busca pelo desenho de um rei completo, cuja imagem se afirma a nível nacional e internacional. Com efeito, o trabalho do retrato, que esteve praticamente ausente nos primeiros séculos da Idade Média, teve um grande interesse nesta cronologia, fazendo viajar a imagem de alguém e selar certos acontecimentos políticos e sociais. Sendo a representação do indivíduo a principal função do retrato, era fundamental que ele estivesse reconhecível, tanto nos seus traços físicos como, se possível, de personalidade. $\mathrm{O}$ retrato garantia o não esquecimento, sendo a arte entendida não só como um caminho importantíssimo para a imortalidade, mas também como uma arma de poder, espelhando a riqueza, os valores e o grau de cultura daquele que a encomenda. $\mathrm{O}$ gosto pelo retrato marcou profundamente o Quattrocento português ${ }^{76}$. Nesta sintonia, é importante salientar que datam do reinado de $\mathrm{D}$. Afonso $\mathrm{V}$ os mais conseguidos e mais complexos retratos pictóricos da realeza portuguesa medieval ${ }^{77}$.

Nas palavras de Dalila Rodrigues, "a relação entre as duas encomendas, tapeçaria e pintura, não exactamente de um ponto de vista artístico, mas no plano das intenções, não pode deixar de se considerar como sendo idêntica e complementar [...]"78. Ao atentar nas Tapeçarias de Pastrana, "[...] o documento coevo mais rigoroso que se conhece, sobre uma ação militar no Séc. XV [...]"79, ou nos Painéis de São Vicente de Fora, rapidamente se compreende que a o soberano não quis apenas imortalizar a imagem de si próprio, mas também da sua geração e do seu reino enquanto um todo.

Se a iconologia do poder real português é habitualmente valorizada apenas a partir do reinado de O Venturoso, coloco-me por completo do lado de Inês Meira Araújo, por entender que as Tapeçarias de Pastrana e os Painéis de São Vicente de Fora são um exemplo por

\footnotetext{
${ }^{76}$ GOMES, Saúl António - op. cit., p. 10.

${ }^{77}$ Idem, p. 9.

${ }^{78}$ RODRIGUES, Dalila - op. cit., p. 34.

${ }^{79}$ RUBIM, Nuno José Varela - "A Artilharia Portuguesa nas Tapeçarias de Pastrana. A Tomada de Arzila em 1471”. Separata da Revista de Artilharia. Lisboa: Academia Militar. [S.1.] (1987). p. 17.
} 
excelência das ambições propagandísticas da dinastia de Avis. A encomenda de obras deste cariz, lega para o futuro a imagem de um rei culto, que carregava "numa mão sempre a espada, e noutra a pena" $" 80$, ainda que a sua estratégia governativa, maculada pelo sangue de Alfarrobeira e de Toro, nem sempre apontasse nesse sentido, motivo que levou alguns autores a encararam o seu governo como um momento de transição e relativo retrocesso entre a regência de D. Pedro e o reinado de seu filho, O Príncipe Perfeito. Diz Rui de Pina que foi o primeiro rei a criar uma livraria no seu paço e, tal como existiram as tapeçarias e os painéis, bem poderiam ter existido outras obras de arte com os mesmos objetivos e ordenadas pelo mesmo monarca. Em suma, a vontade propagandística de O Africano está patente nas suas investidas militares, mas foi nas artes que mais se consumou ${ }^{81}$.

${ }^{80}$ CAMÕES, Luís Vaz de - Os Lusíadas. Lisboa: [s.n.], 1572. Canto VII, estância 79.

${ }^{81}$ ARAÚJO, Inês Filipa Meira - op. cit. 


\section{Fontes Impressas}

CAMÕES, Luís Vaz de - Os Lusíadas. Lisboa: [s.n.]. 1572. Disponível em WWW:<URL: https://oslusiadas.org/i/>. (consultado em 13.01.2020).

HOLANDA, Francisco de - Da Pintura Antiga. In FRANCO, José Eduardo; FIOLHAIS, Carlos (dir.) - Primeiros Tratados de Pintura de MONTEIRO, Patrícia; SERRÃO, Vítor (coord.). "Obras pioneiras da cultura portuguesa, vol. 12". Lisboa: Círculo de Leitores, 2019. pp. 77-283.

PAVIOT, Jacques - Portugal et Bourgogne au XV siècle (1384-1482). Récueil de documents extraits des archives bourguignonnes. Paris/Lisboa: Centre Culturel Calouste Gulbenkian - Commission Nationale pour les Commémorations des Découvertes Portugaises, 1995.

PINA, Rui de - Chronica D’ElRey D. Joaõ II. In PINA, Rui de - Crónicas. Introd. de Manuel Lopes de Almeida; rev. de Manuel Lopes de Almeida. Porto: Lello \& Irmão, 1977. 1054 p.

- - Chronica do Senhor Rey D. Affonso V. In. PINA, Rui de - Crónicas. Introd. de Manuel Lopes de Almeida; rev. de Manuel Lopes de Almeida. Porto: Lello \& Irmão, 1977. 1054 p.

—- Chronica do Senhor Rey D. Duarte. In PINA, Rui de - Crónicas. Introd. de Manuel Lopes de Almeida; rev. de Manuel Lopes de Almeida. Porto: Lello \& Irmão, 1977. 1054 p.

ZURARA, Gomes Eanes de - Chronica dos Feitos da Guiné. In MARKL, Dagoberto L. - $O$ Retábulo de S. Vicente da Sé de Lisboa e os Documentos. Lisboa: Editorial Caminho, $1988.274 \mathrm{p}, 21 \mathrm{~cm}$.

\section{Fontes Iconográficas}

GONÇALVES, Nuno - Painéis de São Vicente de Fora. Óleo e têmpera sobre madeira. Último quartel do século XV. Museu Nacional de Arte Antiga, Lisboa (Portugal).

-Painéis de São Vicente de Fora. Disponível em WWW:<URL: https://pt.wikipedia.org/wiki/Pain $\% \mathrm{C} 3 \% \mathrm{~A} 9$ is de S\%C3\%A3o Vicente de Fora\#/media/Fich eiro:Lagos40 kopie.jpg $>$.

- Painel Cavaleiros. Disponível em $\quad$ WWW: $<$ URL: https://pt.wikipedia.org/wiki/Pain\%C3\%A9is de S\%C3\%A3o_Vicente de Fora\#/media/Fich eiro:Pain $\%$ C3\%A9is de S\%C3\%A30_Vicente de Fora Painel dos Cavaleiros (MNAA, inv. 1365 Pint).png $>$.

-Painel da Relíquiar Disponível em $\quad$ WWW:<URL: https://pt.wikipedia.org/wiki/Pain\%C3\%A9is_de_S\%C3\%A3o_Vicente_de_Fora\#/media/Fich eiro:Pain $\% \mathrm{C} 3 \% \mathrm{~A} 9$ is de $\mathrm{S} \% \mathrm{C} 3 \% \mathrm{~A} 30$ Vicente de Fora Painel da_Rel\%C3\%ADquia_(MNAA, inv. 1362 Pint).png $>$. 
-Painel dos Frades. Disponível em https://pt.wikipedia.org/wiki/Pain\%C3\%A9is de_S\%C3\%A3o_Vicente_de_Fora\#/media/Fich eiro:Pain\%C3\%A9is de S\%C3\%A3o Vicente de Fora_Painel_dos_Frades_(MNAA,_inv._1363_Pint).png $>$.

-Painel dos Pescadores. Disponível em https://pt.wikipedia.org/wiki/Pain\%C3\%A9is de S\%C3\%A3o_Vicente_de_Fora\#/media/Fich eiro:Pain\%C3\%A9is de S\%C3\%A3o Vicente de Fora Painel_dos_Pescadores_(MNAA, inv. 1366_Pint).png $>$.

-Painel do Infante. Disponível em $\quad$ WWW: $<\mathrm{URL}$ : https://pt.wikipedia.org/wiki/Pain\%C3\%A9is de S\%C3\%A3o_Vicente_de_Fora\#/media/Fich eiro:Pain\%C3\%A9is de S\%C3\%A3o Vicente de Fora Painel_do_Infante_(MNAA, inv. 1361_Pint).png>.

-Painel do Arcebispo. Disponível em $\quad$ WWW: $<\mathrm{URL}$ : https://pt.wikipedia.org/wiki/Pain\%C3\%A9is de S\%C $3 \%$ A3o_Vicente de Fora\#/media/Fich eiro:Pain\%C3\%A9is de S\%C3\%A3o Vicente de Fora Painel_do_Arcebispo_(MNAA,_inv. 1364_Pint).png $>$.

GRENIER, Pasquier (oficina de) - Tapeçarias de Pastrana. Último quartel do século XV. Colegiada de Nossa Senhora da Assunção, Pastrana (Espanha).

—Desembarque em Arzila. Disponível em $\quad$ WWW: $<$ URL: https://pt.wikipedia.org/wiki/Tape\%C3\%A7arias_de_Pastrana\#/media/Ficheiro:Landing at_As ilah.jpg $>$.

一 Cerco a $\quad$ Arzila. $\quad$ Disponível em $\quad$ WWW: $<$ URL: https://pt.wikipedia.org/wiki/Tape\%C3\%A7arias de Pastrana\#/media/Ficheiro:O_Cerco de Arzila (Tape\%C3\%A7aria de Pastrana).jpg $>$.

-Assalto a Arzilar Disponível em $\quad$ WWW: $<$ URL: https://pt.wikipedia.org/wiki/Tape\%C3\%A7arias_de_Pastrana\#/media/Ficheiro:Assault_on_A silah.jpg >.

-A Entrada em Tânger. Disponível em WWW: $<$ URL: https://pt.wikipedia.org/wiki/Tape\%C3\%A7arias_de_Pastrana\#/media/Ficheiro:Fall_of_Tangie r.jpg $>$.

HOLANDA, António de; BENING, Simão - A Genealogia do Infante Dom Fernando de Portugal. Introdução, notas, direção artística e gráfica de Martim de Albuquerque e João Paulo de Abreu e Lima. Porto - Lisboa: Banco de Portugal, 1984.

\section{Bibliografia}

ALCAIDE, Victor Nieto; CREMADES, Fernando Checa - El Renacimiento: Formación y crisis del modelo clásico. $3^{\mathrm{a}}$ edição. Madrid: Ediciones Istmo, 1985. 398p.; 18 cm. ISBN 84-7090-108-7.

ARAÚJO, Inês Filipa Meira - As Tapeçarias de Pastrana: Uma Iconografia de Guerra. Lisboa: Faculdade de Letras da Universidade de Lisboa, 2012. 424 p. Tese de mestrado. Disponível em WWW:<URL:https://repositorio.ul.pt/>. (consultado em 12.11.2019).

ATTWATER, Donald - Dicionário de Santos. Trad. de Jorge Pinheiro. Mem Martins: Publicações Europa-América, 1965. 425 p. ISBN972-1-03550-5. 
BLOCH, R. Howard - Misoginia Medieval e a Invenção do Amor Romântico Ocidental. Trad. de Claudia Moraes. Rio de Janeiro: Editora 34, Nova Fronteira, 1995. 280 p. ISBN 8585490-59-4. Disponível em WWW:<URL:https://books.google.com.br/books?hl=pt-

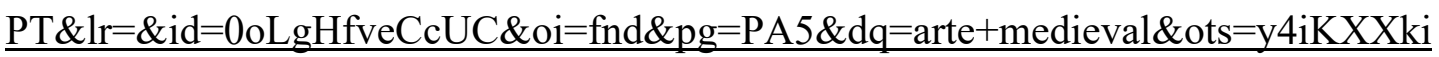
$\underline{Y Y \& \operatorname{sig}=\mathrm{iSILmCG} 6 \mathrm{E} 8 \mathrm{hhjAlcY} 8 \mathrm{prmbG} 9 \mathrm{jdM} \# \mathrm{v}=\text { onepage } \& \mathrm{q}=\operatorname{arte} \% 20 \text { medieval } \& \mathrm{f}=\mathrm{fa}}$

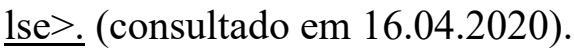

GOMES, Saúl António - D. Afonso V: o africano. Lisboa: Círculo de Leitores, 2006. 366 p. (Coleção Reis de Portugal, 2. dinastia, vol. 12). ISBN 972-42-3815-9.

GUSMÃO, Adriano de - Nuno Gonçalves. Lisboa: Artis, 1958.

HENRIQUES, Ana de Castro (coord.) - A Invenção da Glória: D. Afonso V e as Tapeçarias de Pastrana. Lisboa: Museu Nacional de Arte Antiga, 28 de maio de 2010. 104 p. ISBN 978-972-776-404-4.

HOLANDA, António de; BENING, Simão - A Genealogia do Infante Dom Fernando de Portugal. Introdução, notas, direção artística e gráfica de Martim de Albuquerque e João Paulo de Abreu e Lima. Porto - Lisboa: Banco de Portugal, 1984.

LACALLE, Ana Valtierra - "La Palmera y la Palma. Adaptación Medieval de una Antigua Iconografía". Revista Digital de Iconografia Medieval. [Em Linha] Madrid: Universidad Complutense. N. ${ }^{\circ} 17$ (2017) pp. 105-124. Disponível em WWW:<URL: https://www.ucm.es/bdiconografiamedieval/rdim>. (consultado em 17.11.2019).

LEMAÎTRE, Nicole; QUINSON, Marie-Thérèse; SOT, Véronique - Dicionário Cultural do Cristianismo. Trad. de José David Antunes. Lisboa: Publicações Dom Quixote, 1999. ISBN 972-20-15206.

MAGALHÃES, Joaquim Romero de (coord.) - No Alvorecer da Modernidade (1480-1620). In MATTOSO, José (dir.) - História de Portugal, vol. 3. Lisboa: Editorial Estampa, Outubro de 1997. ISBN 972-33-1334-0. Vol. 3.

MARKL, Dagoberto L. - O Retábulo de S. Vicente da Sé de Lisboa e os Documentos. Lisboa: Editorial Caminho, agosto de 1988. 274 p, $21 \mathrm{~cm}$.

MARTINS, Fausto S. - “Aspetos Polémicos dos Painéis de São Vicente: Ritual e Iconografia”. Revista da Faculdade de Letras: Ciências e Técnicas do Património. [Em Linha] Porto: Faculdade de Letras - Universidade do Porto. Vol. 2 (2003) pp. 267-290. Disponível em WWW:<URL:https://hdl.handle.net/10216/8201>. (consultado em 23.09.2019). 
NEGREIROS, José Almada de - Almada. Os Painéis, a Geometria e Tudo. As entrevistas com António Valdemar. Prefácio de José Manuel dos Santos. Porto: Assírio \& Alvim, setembro de 2015. ISBN 978-972-1842-3.

PANOFSKY, Erwin - Estudos de Iconologia. Lisboa: Editorial Estampa, 1995. 240 p. ISBN 9789723310184.

PICOITO, Pedro; VICENTE, Filipe Nunes; JORGE, Luís M. - A nau e os corvos: São Vicente $e$ as armas de Lisboa. [s.1.]: Declínio e Queda, 2013. Disponível em WWW:<URL:https://declinioqueda.wordpress.com/2013/06/08/a-nau-e-os-corvossao-vicente-e-as-armas-de-lisboa/> [original]; <URL: http://web.archive.org/web/20210706091151/https://declinioqueda.wordpress.com/201 $\underline{\text { 3/06/08/a-nau-e-os-corvos-sao-vicente-e-as-armas-de-lisboa/> }}$ [arquivado].

PIMENTEL, António Filipe - D. Afonso V e a Invenção da Glória. As Tapeçarias de Pastrana no Museu Nacional de Arte Antiga. In HENRIQUES, Ana de Castro (coord.) $-A$ Invenção da Glória: D. Afonso V e as Tapeçarias de Pastrana. Lisboa: Museu Nacional de Arte Antiga, 28 de maio de 2010. 104 p. ISBN 978-972-776-404-4.

RAMOS, Manuel Francisco - “«Mulier ne debuerit habere regnum»: a regência na menoridade de D. Afonso V vista pelos juristas”. Medievalista. [Em Linha]. Lisboa: IEM-FCSH. N. 23 (2018) Disponível em https://medievalista.iem.fcsh.unl.pt/index.php/medievalista/article/view/113 > .

REVILLA, Federico - Diccionario de Iconografia. Madrid: Ediciones Cátedra, 1990. 404 p. ISBN 84-376-0929-1.

RODRIGUES, Dalila - As tapeçarias de Pastrana e os painéis de São Vicente. Legado artístico e memória simbólica do reinado de Afonso V. In HENRIQUES, Ana de Castro (coord.) - A Invenção da Glória: D. Afonso V e as Tapeçarias de Pastrana. Lisboa: Museu Nacional de Arte Antiga, 28 de maio de 2010. 104 p. ISBN 978-972-776-404-4.

RUBIM, Nuno José Varela - “A Artilharia Portuguesa nas Tapeçarias de Pastrana. A Tomada de Arzila em 1471”. Separata da Revista de Artilharia. Lisboa: Academia Militar. [S.1.] (1987).

THOMAZ, Luís Filipe Reis - De Ceuta a Timor. 2a ed. Linda-a-Velha: Difel, 1998. ISBN $972-$ 29-0308-X. 


\section{Anexos}

\section{Quadro 1: Comparação entre os capítulos $213^{\circ}$ da Crónica de D. Afonso V e $82^{\circ}$ da Crónica de D. João II}

\begin{tabular}{|c|c|c|}
\hline Caraterísticas & Crónica de D. Afonso $V$ & Crónica de D. João II \\
\hline Aspeto físico & $\begin{array}{l}\text { “[...] mais de grande que meaã } \\
\text { estatura, e em todos os seus } \\
\text { membros bem feyto e muy } \\
\text { proporcionado [...] teve ho rosto } \\
\text { redondo, bem povoado de barba } \\
\text { preta, e em todallas outras partes do } \\
\text { corpo muyto cabeludo, salvo na } \\
\text { cabeça, em que depois dos trinta } \\
\text { anos começou de ser calvo."1 }\end{array}$ & $\begin{array}{c}\text { "[...] homem de corpo, mais grande, que pequeno, } \\
\text { muy bem fecto, e em todos seus membros mui } \\
\text { proporcionado; teve ho rosto mais comprido, que } \\
\text { redondo, e de barba em boa conveniencia povoado. } \\
\text { Teve os cabellos da cabeça castanhos, e corredios; e } \\
\text { porem em hidade de trinta e sete annos, na cabeça, e } \\
\text { na barba era ja mui caão [...] e os olhos de perfeita } \\
\text { vista }[. . .] \text {, ho nariz teve hũ pouco comprido, e } \\
\text { derribado algũ sem fealdade."2 }\end{array}$ \\
\hline $\begin{array}{c}\text { Traços de } \\
\text { personalidade }\end{array}$ & $\begin{array}{l}\text { "Foy Pryncepe de muy graciosa } \\
\text { presença, grande humanydade, e } \\
\text { doce conversaçam [...] Foy de } \\
\text { grande memoria, e maduro entender, } \\
\text { e de sotil engenho [...] Pryncepe de } \\
\text { muy alto e esforçado coraçam, foy } \\
\text { sempre zellador de emprender } \\
\text { cousas arduas, e prosseguyllas por } \\
\text { armas como cavaleiro, mais que de } \\
\text { entender como Rey no Regimento } \\
\text { Civel e Polytico de Reynos [...]"3 }\end{array}$ & $\begin{array}{c}\text { "Foy Princepe de maravilhoso engenho, e subida } \\
\text { agudeza, e mui mixtico pera todalas cousas; e a } \\
\text { confiança grande que disso tynha, muitas vezes lhe } \\
\text { fazia confiar mais de seu saber, e creo conselhos } \\
\text { d'outrem menos do que devia. Foy de mui viva, e } \\
\text { esperta memoria [...] Foy Rey de mui alto, esforçado, } \\
\text { e sofrido coraçam [...]"4 }\end{array}$ \\
\hline $\begin{array}{c}\text { Aplicação da } \\
\text { justiça }\end{array}$ & $\begin{array}{c}\text { "[...] remysso mais que trigoroso nas } \\
\text { graves execuçoẽs. Especialmente } \\
\text { nas da justiça que tocavam contra } \\
\text { grandes pessoas, a quaaes mais } \\
\text { folgava de dessymullar ou temperar } \\
\text { brandamente, que executallas com } \\
\text { rigor }[. . .] " 5\end{array}$ & $\begin{array}{c}\text { "Foy Princepe mui justo, e mui amigo de justiça, e } \\
\text { nas exucuções della mais rigoroso, e severo, que } \\
\text { piedoso; porque sem algũa exçepçam de pessoas de } \\
\text { baixa, e alta condiçam, foy della mui inteiro exuqutor } \\
\text { [...] as leys que a seus vassallos condanavam, nunca } \\
\text { quis que a si mesmo asolvessem; ca seendo Senhor } \\
\text { das leys, se fazia logo servo dellas, pois lhe primeiro } \\
\text { obedecia [...]"6 }\end{array}$ \\
\hline $\begin{array}{c}\text { Literacia e } \\
\text { oratória }\end{array}$ & $\begin{array}{l}\text { "Suas pallavras no que queria dizer } \\
\text { eram sempre bem ordenadas, e } \\
\text { entoadas com muy gracioso orgam, } \\
\text { e per pena, de seu natural escrevia } \\
\text { assy bem, como se per longo ensyno } \\
\text { e exercicio d'oratoria artificialmente } \\
\text { o aprendera, foy amador [...] de } \\
\text { ciencia, e honrou muyto os que a } \\
\text { sabiam. Foy o Prymeiro Rey destes } \\
\text { Reynos que ajuntou boõs livros e fez } \\
\text { livraria em seus paços [...]"7 }\end{array}$ & $\begin{array}{l}\text { "[...] teve ho juizo craro, e profundo: e porem suas } \\
\text { Sentenças, e fallas que inventava, e dezia, tinham } \\
\text { sempre na envençam mais de verdade, agudeza, e } \\
\text { autoridade, que de doçura, nem ellegancia nas } \\
\text { palavras, cuja pronunciaçam foy vagarosa, entoada } \\
\text { algũ tanto pelos narizes, que lhe tirava algũa graça." }\end{array}$ \\
\hline $\begin{array}{l}\text { Relação com } \\
\text { os súbditos }\end{array}$ & $\begin{array}{l}\text { "[...] foy o primeiro Rey que pellas } \\
\text { praças e lugares pubrycos das } \\
\text { Cidades e Vyllas de seus Reynos fez } \\
\text { a todos muy famyliar sua vista }[. . .] " 9\end{array}$ & $\begin{array}{l}\text { "[...] Senhor de Senhores nunca quis ser, nem parecer } \\
\text { servo dos servidores: e disto principalmente procedia, } \\
\text { que em sua vida foy avido por secco de condiçam, e } \\
\text { nom humano, nem pareceo em vivendo de todos assi }\end{array}$ \\
\hline
\end{tabular}

${ }^{1}$ PINA, Rui de - Chronica do Senhor Rey D. Affonso V... p. 880.

2 PINA, Rui de - Chronica D’ElRey D. Joaõ II. In PINA, Rui de - Crónicas. Introd. de Manuel Lopes de Almeida; rev. de Manuel Lopes de Almeida. Porto: Lello \& Irmão, 1977. p. 1029.

${ }^{3}$ PINA, Rui de - Chronica do Senhor Rey D. Affonso V... pp. 880-881.

${ }^{4}$ PINA, Rui de - Chronica D’ElRey D. Joaõ II... pp. 1029-1030.

${ }^{5}$ PINA, Rui de - Chronica do Senhor Rey D. Affonso V... p. 880.

${ }^{6}$ PINA, Rui de - Chronica D’ElRey D. Joaõ II... p. 1030.

${ }^{7}$ PINA, Rui de - Chronica do Senhor Rey D. Affonso V... p. 880.

${ }^{8}$ PINA, Rui de - Chronica D'ElRey D. Joaõ II... pp. 1029-1030.

${ }^{9}$ PINA, Rui de - Chronica do Senhor Rey D. Affonso V... p. 880. 


\begin{tabular}{|c|c|c|}
\hline & & $\begin{array}{l}\text { amado, e estimado, como ho foy despois de sua } \\
\text { morte. Mas este novo, tam grande, e tam geral amor, } \\
\text { que a elle, e a sua memoria per todos despois sobreveeo, } \\
\text { nom naçeo tanto dos merecimentos de seu corpo, em } \\
\text { que ouve muitos, e de grande louvor, como da gloriosa } \\
\text { salvaçam, e bem aventurança de sua alma [...]"10 }\end{array}$ \\
\hline $\begin{array}{l}\text { Capacidade } \\
\text { bélica }\end{array}$ & $\begin{array}{l}\text { "Foy tam confiado de seu saber, que } \\
\text { com difyculdade queria estar per } \\
\text { alheos conselhos se contradiziam } \\
\text { sua vontade, especialmente nas } \\
\text { cousas da guerra dos Mouros, em } \\
\text { cujo prosseguimento foy sempre tam } \\
\text { aceso e inclinado, que acerca disso } \\
\text { todo seu apetito lhe pareciam vivas } \\
\text { rezoões [...]"11 }\end{array}$ & $\begin{array}{c}\text { "[...] foy singular cavalgador, especialmente da } \\
\text { gineta, deestro, braceiro [...]. Foy grande Monteiro, } \\
\text { mas muito maior caçador d'altanaria, a que era mui } \\
\text { incrinado }[\ldots] " 12\end{array}$ \\
\hline $\begin{array}{l}\text { Fervor } \\
\text { religioso }\end{array}$ & $\begin{array}{c}\text { "[...] foy Pryncepe muy Catolico e } \\
\text { amigo de Deos, e mui fervente na } \\
\text { fée, ouvia continuada e muy } \\
\text { devotamente os Offycios Divinos } \\
{[\ldots] " 13}\end{array}$ & $\begin{array}{l}\text { "Foy sobre tudo Princepe mui devoto, e amigo de } \\
\text { Deos, e nunca o Nome de JESUS chegou a suas } \\
\text { orelhas, que o nom recebesse no coraçam co os } \\
\text { giolhos em terra: nem se passou dia em que com } \\
\text { muita devaçam nom ouvisse Missa, e os Officios } \\
\text { Divinos; nem nocte que em seu Oratorio secreto nom } \\
\text { rezasse, e s'encomendasse a Deos [...] E pera se o } \\
\text { Culto Divino celebrar, e fazer perfeitamente, e com } \\
\text { muita solepnidade, trouxe sempre em sua Capella } \\
\text { muitos Capellaães, e singulares cantores."14 }\end{array}$ \\
\hline Virtudes & $\begin{array}{l}\text { "Foy no comer, beber, e dormir muy } \\
\text { regrado, e sobre tudo de muy } \\
\text { louvada continencia; porque avendo } \\
\text { nom mais de XXXIII annos, ao } \\
\text { tempo que a Raynha sua molher } \\
\text { falleceo [...] foy despois acerca de } \\
\text { molheres muy abstinente, ao menos } \\
\text { cauto [...] Folgou muyto d'ouvir } \\
\text { musica, e de seu natural sem algum } \\
\text { arteficio teve pera ella bom } \\
\text { sentimento."15 }\end{array}$ & $\begin{array}{l}\text { "Foy Princepe sobre todos em suas detriminações } \\
\text { tam constante, e nas palavras tam verdadeiro, que em } \\
\text { sua soo palavra, quando a dava, hiam os homens } \\
\text { mais contentes, e seguros, do que poderiam hir nos } \\
\text { assinados, e selos de muitos. [...] Foy manhoso, e } \\
\text { desenvolto em todalas boas manhas, que a hũ alto } \\
\text { Princepe convem [...] sempre se prezou d'andar bem, } \\
\text { e ricamente vestido [...]. Foy homem que comeo } \\
\text { bem, e porem nunca mais de duas vezes por dia, e } \\
{[\ldots . .] \text { sempre bebeo agoa, e nunca vinho. Foy em todas }} \\
\text { suas palavras muy honesto, e temperado, e no auto da } \\
\text { carne acerqua de molheres, despois de ser Rey, foi } \\
\text { sobre todos mais continente."16 }\end{array}$ \\
\hline $\begin{array}{l}\text { Administração } \\
\text { do reino }\end{array}$ & $\begin{array}{c}\text { "E na nobreza e liberalidade teve } \\
\text { sem medyda tanta parte, que mais } \\
\text { propriamente se podia dizer prodigo } \\
\text { que verdadeiro liberal, } \\
\text { especialmente nas cousas da Coroa } \\
\text { do Reyno, de que sem grandes } \\
\text { merecimentos nem muyta } \\
\text { necessydade, mas por soos manhas e } \\
\text { praticas que com elle os grandes } \\
\text { husavam, a desguarneceo e } \\
\text { mynguou em pouca parte." } 17\end{array}$ & $\begin{array}{c}\text { "E assi fez, e ordenou outras muitas, e boas cousas, e } \\
\text { de muito bem, proveito, e boa governança de seus } \\
\text { Regnos, vassallos, e naturaaes deles, em que pareceo } \\
\text { mui claro, que era proprio, e verdadeiro coraçam da } \\
\text { Repubrica."18 }\end{array}$ \\
\hline
\end{tabular}

\footnotetext{
${ }^{10}$ PINA, Rui de - Chronica D’ElRey D. Joaõ II... p. 1030.

${ }^{11}$ PINA, Rui de - Chronica do Senhor Rey D. Affonso V... p. 881.

${ }^{12}$ Idem, p. 1031.

${ }^{13}$ PINA, Rui de - Chronica do Senhor Rey D. Affonso V... p. 881

${ }^{14}$ PINA, Rui de - Chronica D'ElRey D. Joaõ II... p. 1032.

${ }^{15}$ PINA, Rui de - Chronica do Senhor Rey D. Affonso V... p. 881

${ }^{16}$ PINA, Rui de - Chronica D'ElRey D. Joaõ II... pp. 1030-1031.

${ }^{17}$ PINA, Rui de - Chronica do Senhor Rey D. Affonso V... p. 881.

${ }^{18}$ PINA, Rui de - Chronica D'ElRey D. Joaõ II... p. 1032.
} 